\title{
UNRECOGNIZABLE, ABANDONED, UNNAMED, AVOIDED PLACES: ON THE MURDERS COMMITTED AGAINST JEWS IN POLAND IN THE PERIOD AFTER THE SECOND WORLD WAR AND THEIR COMMEMORATION
}

\begin{abstract}
The fall of the Third Reich, turning the "most tragic page" in the history of the Jewish nation, i.e. the Second World War, did not mean the end of the tragedy for Jews on Polish soil. Even before the end of the greatest conflict in the history of humankind, in the areas liberated from Nazi Germany occupation, many survivors of the Holocaust experienced acts of ruthless violence. However, very few of the numerous victims of the post-war anti-Jewish terror have been commemorated in public space. To a very small extent the form of public commemoration also covered earlier wartime cases of collective murders committed against Jews by Polish Christians. Even if the sites of the dramatic events which occurred in the shadow of the Holocaust were marked, the complete truth about their course was not restored everywhere. Key words: Jews, the Holocaust, anti-Jewish violence, post-war period, sites of memory, sites of non-memory, non-sites of memory.
\end{abstract}

\section{INTRODUCTION - THE MAJORITY VERSUS THE MINORITY IN EFFORTS TO COMMEMORATE IMPORTANT PLACES IN THE CULTURAL LANDSCAPE}

The development of national awareness among groups of the population connected by a more or less well-formed sense of distinctiveness (including the ability to transmit this self-identification towards various initiatives in the field of collective

\footnotetext{
* Andrzej RYKAŁA, University of Lodz, Faculty of Geographical Sciences, Department of Political, Historical Geography and Regional Studies, ul. Kopcińskiego 31, 90-142 Łódź, Poland; e-mail: andrzej.rykala@geo.uni.lodz.pl, ORCID: https://orcid.org/0000-0002-2183-3103

(C) by the author, licensee Łódź University - Łódź University Press, Łódź, Poland. This article is an open access article distributed under the terms and conditions of the Creative Commons Attribution license CC-BY-NC-ND 4.0 (https://creativecommons.org/licenses/by-nc-nd/4.0/)
} 
life) takes place in the most desirable way in conditions where such communities assume institutionalised, especially state-like forms. They provide a legal, administrative and economic framework for these communities, complementing and strengthening their existence. The comfort of an unrestricted existence in an area demarcated by political borders is usually provided to a national (religious) majority. Individuals in smaller communities are often unable to exercise the privileges and rights assigned to the dominant group. This is also the case today, despite the fact that in democratic states of law, great importance is attached to protecting these communities. Inequitable relations between the majority and ethnic minorities leave their mark, apart from numerous areas of life, also in space: in the ways and forms it is occupied, organised, marked, named, and commemorated ${ }^{1}$.

Jews, one of the minorities in Poland, remained for centuries in complex, though unequal relations with the Catholic nation (initially mainly the nobility), whose broadly understood interests were guarded by those in power, almost entirely identifying themselves with the Catholic majority. Pushed, with varying dynamism and often selectively, to the margins of social life, obliged for most of the time of their presence on the Polish lands to occupy the places indicated to them in space and organise them in a way not always consistent with their own needs, they were still met by those in power with relative respect for their cultural diversity: a relatively unrestricted material existence and a certain freedom of religious practices. The consequence of such an arrangement of relations was the formation in Poland, over several centuries, of the largest concentration of the Jewish nation in the world, being at the same time the most important intellectual and cultural centre of this community. However, this exceptional legacy lay in ruins in the middle of the $20^{\text {th }}$ century as a result of the Jewish extermination by the Third Reich. It consumed the lives of 3 million Polish Jews $(90 \%$ of the total population) (Adelson, 1993, p. 387; Cała and Datner-Śpiewak, 1997, p. 9; Datner and Melchior, 1997, pp. 70-71; Rykała, 2007, p. 17; Eberhardt, 2010, p. 93, 107, 110; 2011, p. 78, 88, 92; Stankowski and Weiser, 2011, pp. 31-34; Żbikowski, 2017, p. 9; Rosner, 2018, p. 100). As a result of the barbaric actions of the "enraged Nazi bandits"2, the material and spiritual culture, forming over a thousand years and unique in the history of the Jewish nation, was irretrievably destroyed.

There is not even a trace left of many human beings murdered in mass killing sites. Without even such a dimension of anchoring in reality, their closest ones were deprived of the opportunity to mourn the victims. One of the "sons" of the Jewish

\footnotetext{
${ }^{1}$ These mutual systems of coordinates are reflected in the cultural landscape, which is the result of the transformation - broadly speaking - of the natural landscape under the influence of civilisation development. Such a landscape consists of all observable objects which are a form of a combination of natural and anthropogenic interactions.

${ }^{2}$ Archive of the Jewish Historical Institute (AŻIH), Central Committee of Jews in Poland (CKŻP), Bureau and Agency (PiS), 303/I/7. From the proclamation "Almost all of Poland is free".
} 
people expressed his poetic exultation at the impossibility of bowing his head to the fate of the victims in the places where their lives were interrupted, writing:

We, who will not ever find the graves of our children and our mothers - they are layered so, that they would cover the entire land were they to be buried one next to the other! And there will not be one spot where you could lay flowers, but like the sower casting his seed, you will cast them about. Through some coincidence, you may find the spot (Tuwim, 1993, p. 18).

The feeling of deep sadness caused by the mass of the Holocaust victims resting on the Polish soil - the cemetery of the Jewish nation, unable to count on collective sympathy, was also expressed by Lieutenant Colonel Dr. Dawid Kahane, the Chief Rabbi of the Polish Army. He spoke the following words over the graves of those murdered on 4 July 1946 in the Kielce pogrom:

In large and small towns and villages, and often in the open field, there are rows of graves surrounded by rails. In spring, when the fields and forests are filled with greenery, on All Souls' Day or other solemn occasion, banners will bow down over these graves, someone's hand will throw flowers on them, some lonely tear will fall.

With us Jews it's different. We, Polish Jews know other graves, whose unexpected presence will make a passer-by bridle up. The graves scattered ... like field stones, thrown with the inconsiderate hand of fate.

Those who lay in these graves knew when they went to their death that no one would put the tombstone over their grave, no one would say the Kadish, no one would hum El Malei Rachamim. (Nad mogiła Męczenników..., 1946, p. 7).

The impossibility to express topographically numerous places marked by death or suffering and put them in the order of cultural perception of the landscape was accompanied by a depressing reflection on the inevitable destruction of the existing Jewish cemetery heritage, first by the Nazi occupying forces and then by the Polish (Fig. 1-4). This was put into words in a poignant and penetrating way by Kazimierz Wyka (1945), a historian and literary critic:

There are towns in Poland, in whose pavements you trample remnants of such stones, fragments of Hebrew inscriptions unreadable to you. The empty space of the cemetery is covered with grass. A stone has been saved here and there. They're playing cards on it or they're laying out the goods. There are paths leading through breaches in the cemetery walls. ... this cemetery is triply dead. No one throws pieces of paper on the grave under the tree. ... whoever fails to see the meaning of these empty walls, behind which a Levantine crowd of Polish origin swarms, is immensely dark. Dark to one of the greatest misfortunes and crimes history knows.

However, the approaching end of the Second World War and the inevitable defeat of Hitler's Germany did not stop the suffering of Jews in Poland. In areas abandoned by German occupation forces many survivors (frightened, often homeless, lonely, struggling with trauma and pain after the loss of their relatives) were still subjected to violence. Those guilty of anti-Jewish terror were usually not identified, and even if their identity was established, the acts they had committed 
did not prevent them in modern Poland from being granted the honour of inclusion in the pantheon of heroes of history written by the majority (Fig. 5) ${ }^{3}$.
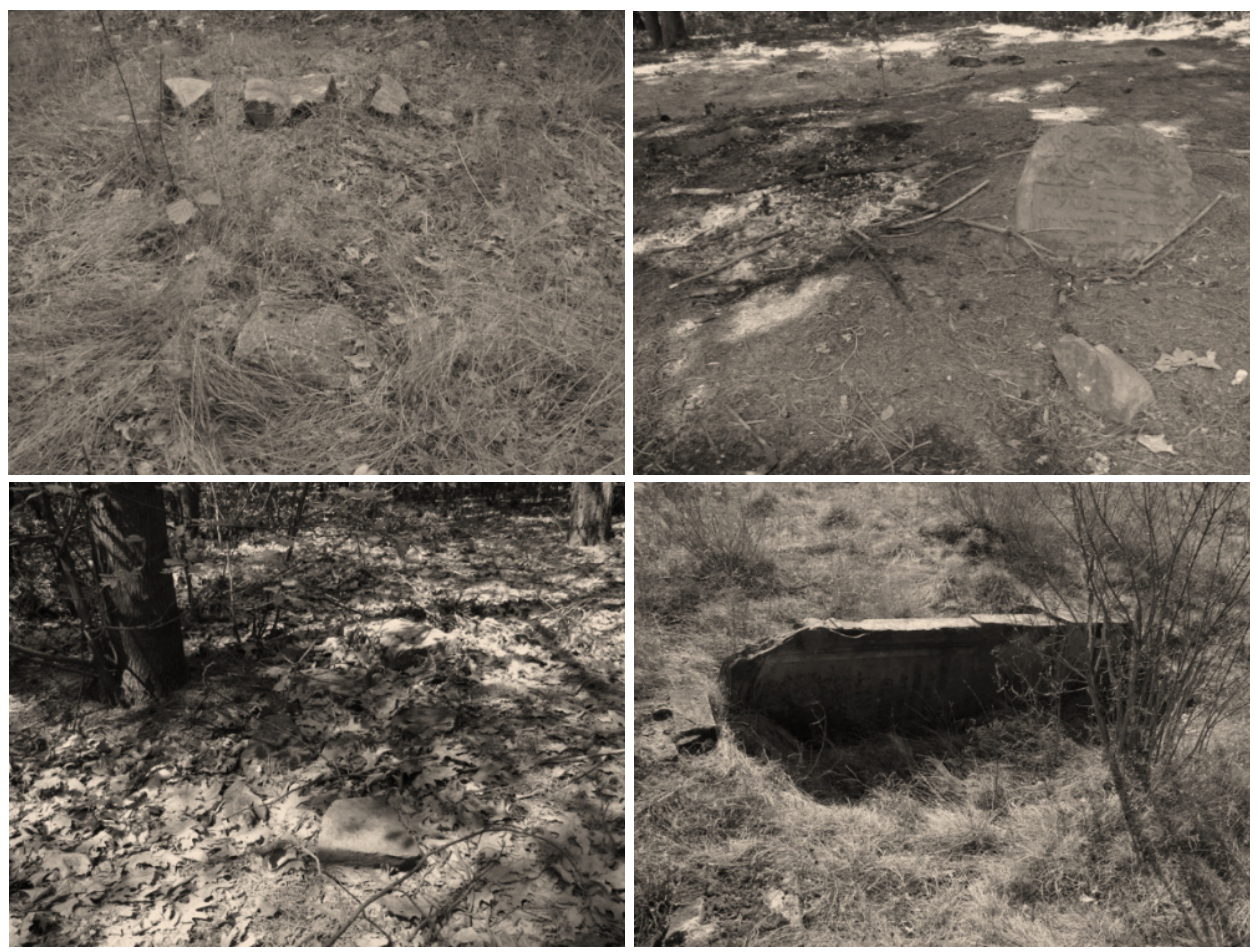

Fig. 1-4. Jewish necropolises in Tresta (Żarnów), Przedbórz, Ozorków and Rozprza

Source: own archive (2012).

\footnotetext{
${ }^{3}$ Emblematic examples include Józef Kuraś, nom-de-guerre Ogień, responsible, among others, for the murders of Jews in Podhale, or Romuald Rajs, nom-de-guerre Bury, the perpetrator of genocide committed on Orthodox inhabitants of Podlasie. The anti-communist underground unit under the command of the former was charged with the murder of 12 Jews, carried out in the vicinity of Krościenko on May 2, 1946, Archive of New Files (AAN), Ministry of Public Administration (MAP), Political Department (DP), Department of Nationalities (WN), ref. 787. A copy of a letter from Dr. Horowitz, the president, and Dr. Reichman, Secretary General of the Provincial Jewish Committee in Cracow, addressed to the Central Committee of Jews in Poland, May 4, 1946, on the murder of Jews at Krościenko; AŻIH, CKŻP, PiS, 303/I/11. Minutes of the meeting of the Bureau of the CKŻP held on 8 May 1946; AZIH, CKŻP, Central Special Commission (CKS), ref. 303/XVIII/20. A list of murders committed against the Jewish population; see also: Cała and Datner-Śpiewak, 1997, pp. 44-45; Gross, 2008, p. 58; Kwiek, 2013, pp. 688-694. Among the anti-communist partisans, it is to this warlord of the armed underground that the most deaths among the surviving Jews are attributed (Grabski, Rykała, 2010, p. 403). More about the massacre near Krościenko, among others in: Wójcik, 2016, on the genocide by the Rajs squad - Moroz, 2015, pp. 61-91. See also about the pacification of Belarusian villages by Bury: Alina Pospischil's interview with Adam Puławski, IPN wyrzuca naukowców... 2018, p. 22.
} 


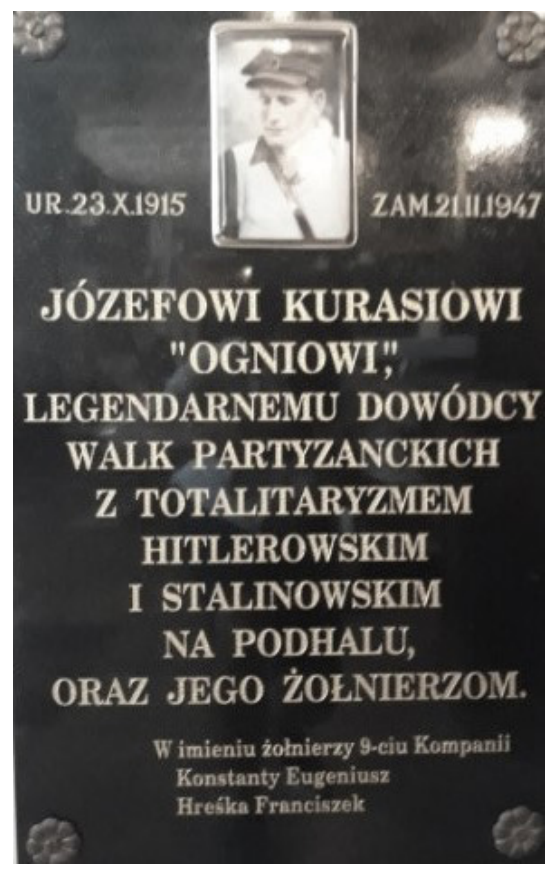

Fig. 5. A plaque in the church of St. Stanislaus Kostka in Warsaw to commemorate Józef Kuraś, alias Ogien, responsible, among others, for the murder of Jews who survived the Holocaust

Source: own archive (2019).

In turn, the sites of these traumatic events, marked by the suffering and death of Holocaust survivors, have not become points that would spark memory in local or supralocal communities. They have arranged themselves, 'spread out' into another layer of "burial", without a "spot" to lay flowers, on which "no one will put a tombstone over their grave, no one will say the Kadish."

The main objectives of the article include:

- to discuss selected acts of collective violence against the Jewish population in the areas conquered by the Third German Reich in the mid-1941, which until then had been under the occupying jurisdiction of the Soviet Union;

- to analyse (using selected examples) the topographical marking of information about anti-Jewish terror from that period;

- to explain the causes and analyse the socio-political and spatial conditions of anti-Jewish violence in Poland after the Second World War;

- to restore the memory of the Jewish victims of murders and the sites where they occurred, as well as to reflect on their commemoration.

The time span of the analysis is determined by, on the one hand, the liberation of particular lands from the German occupation, and, on the other, the beginning (in February 1946) of the repatriation of the Jewish population from the Soviet Union. 


\section{IN THE SHADOW OF THE HOLOCAUST AND IN CO-OPERATION WITH ITS MAIN PERPETRATORS. ON COMMEMORATING EVENTS INCONVENIENT FOR THE NATIONAL MAJORITY IN THE CULTURAL LANDSCAPE}

In reference to this annihilation of the Jewish community in Poland, unique throughout history, revealing "what abysses of humiliation and barbarism the 'Third Reich' have reached"4, it should be added that in the shadow of the Holocaust, and not infrequently also in co-operation with its main perpetrators, aggression and terror were also committed by "numerous sons of the Polish nation"s.

The greatest number of acts of collective anti-Jewish violence, which were horrifying in scale, occurred in the areas conquered by the Third Reich in the mid1941, previously under the occupation of the Soviet Union. Within the borders of contemporary Poland, these were primarily Podlasie and eastern Masovia, areas that were poorly urbanised and backwards in terms of civilizational development.

Jews were a large portion of the local population, in some towns exceeding $50 \%$ (Fig. 6). In addition to their demographic potential, they also made an important contribution to the development of trade and crafts in the area (see, e.g.: Urynowicz, 2002, pp. 86-101).

The wave of violence, which was a sequence of several dozen collective acts against the Jewish population, spread over these lands in June and July 1941, i.e. the period when the occupying German authorities were installing their rule. Those guilty of this persecution - Polish neighbours (Christians) - blamed Jews of having pro-com-

\footnotetext{
${ }^{4}$ AŻIH, Central Jewish Historical Commission (CŻKH), ref. 303/XX/38. Objectives and tasks of CŻKH in Poland developed by F. Friedman, the Centre's director.

${ }^{5}$ This phrase was used by Simcha "Kazik" Rotem, an insurgent from the Warsaw Ghetto. He was prompted to do so by the amendment to the Act on the Institute of National Memory (IPN), which stipulates penalisation any suggestions that the Polish state or nation participated or were complicit in the crimes committed by the Third Reich. Expressing his protest (in a letter addressed to the Polish President) against the attempts of the currently governing Polish political party to introduce a legal muzzle for undertaking scientific research related to the Second World War, Rotem stated that "numerous sons of the Polish nation actively participated in the extermination of the Jewish nation in Poland during the Holocaust, in the deportation of Jews from their places of residence in Poland, while cruelly oppressing us," (Rotem, 2018). Cases of Polish complicity in crimes against Jews, identified on the basis of abundant source materials, especially the decree of the Polish Committee of National Liberation of 31 August 1944, have been scientifically analysed by, among others, B. Engelking (2011) in her work Jest taki piękny słoneczny dzień. Losy Żydów szukających ratunku na wsi polskiej 1942-1945, J. Grabowski (2011) in Judenjagd. Polowanie na Żydów 1942-1945. Studium dziejów pewnego powiatu, and both authors as editors of Zarys krajobrazu. Wieś polska wobec zagłady Żydów 1942-1945 (2011). The complicity of part of the Polish nation in the extermination of their Jewish co-citizens, documented and divided into districts, was also the research problem of the last work edited by both researchers entitled Dalej jest noc. Losy Żydów w wybranych powiatach okupowanej Polski, vol. 1 and 2 (2018).
} 
munist attitudes and collaboration with the Soviet occupying forces, which was to be expressed in their "over-representation" in the structures of the local administration. However, contrary to the stereotype of the general approval of the Jewish community for the policy of the Soviet authorities - declaring equal rights and a fight against all manifestations of ethnic hatred - the representation of Jews who were allowed to participate in the structures of power was not, as A. Żbikowski (2006, pp. 235-237) has estimated, numerous ${ }^{6}$, and the instances of expelling them deep into the Soviet Union included proportionally more of them than the rest of the population.

German policy in the newly conquered territory was to incite acts of collective violence against the Jews living there. Those were perpetrated by the local population, mobilised by anti-communist political activists interested in suppressing the ideology hostile to Hitlerism and determined to crack down on Jews, who were seen as communism's primary base. Poles were to be activated in order to incite riots, among other things, by the negative attitude of some of them towards the Jewish population and their willingness to take over the property belonging to them. The source of these attitudes was, as A. Żbikowski (1992, p. 7) has put it, rooted in a centuries-old system of mutual references, comprehensive contacts, and mutual observation.

\footnotetext{
${ }^{6}$ The approval of a part of the Jewish community for the occupying Soviet authorities resulted both from the negative experiences of life in the inter-war, anti-Semitism-ridden Republic of Poland, and from their awareness of the tragic consequences of being under German jurisdiction. The affirmative attitude towards the Soviets stemmed from a hope - fed by the communist doctrine - for a government of social justice, free of any form of discrimination against the Jewish minority. As interpreted by B. C. Pinchuk (1991), Jews used this favourable attitude to compensate themselves for the legal and economic handicap they had suffered in the inter-war period. The Soviet authorities made socio-technical efforts to gain support from this numerous ethnic group living in the territory they just acquired. Their aim was to eliminate any manifestations of national autonomy, leading to the formation of a classless society, incapable of voicing attitudes of discrimination on ethnic or religious grounds. However, the socio-technical methods used to achieve this goal deprived Jews of their most important group distinctions. Among other things, they led to the liquidation of religious communities, they banned the use of the Hebrew language, which was gaining popularity in Zionist circles, and forced the transfer of religious activity from the public to the private (home) sphere. Economic life was also transformed by the new regulations. As a result of new taxes, administrative pressure (paragraph 11 aimed at "class enemies") and police pressure (exiles), the merchant class was almost entirely eliminated. The second most numerous professional group of tradesmen, the craftsmen, were concentrated into cooperative artels. The community, undergoing complex transformations and indoctrination, was also deprived of their authorities. Socialist activists belonging to the anti-communist Bund party were arrested, while Zionist group members managed to cross to Lithuania. Other party members abandoned their previous activities to cooperate with the Soviets, taking up positions in local administrations. Concurrently with the ongoing indoctrination, which led to a deepening inertia in the Jewish community, external signs of anti-Semitic behaviour have been eliminated, thus contributing to an illusory sense of real equality. Such interdependencies with the new government led Jews to a kind of symbiosis with it, which in turn caused a hostile reaction from the Polish majority triggered by the social advancement of the Jewish minority, even though Poles were also engaged in forming the Soviet administrative structures. See also: Pinchuk, 1991; Żbikowski, 1992.
} 


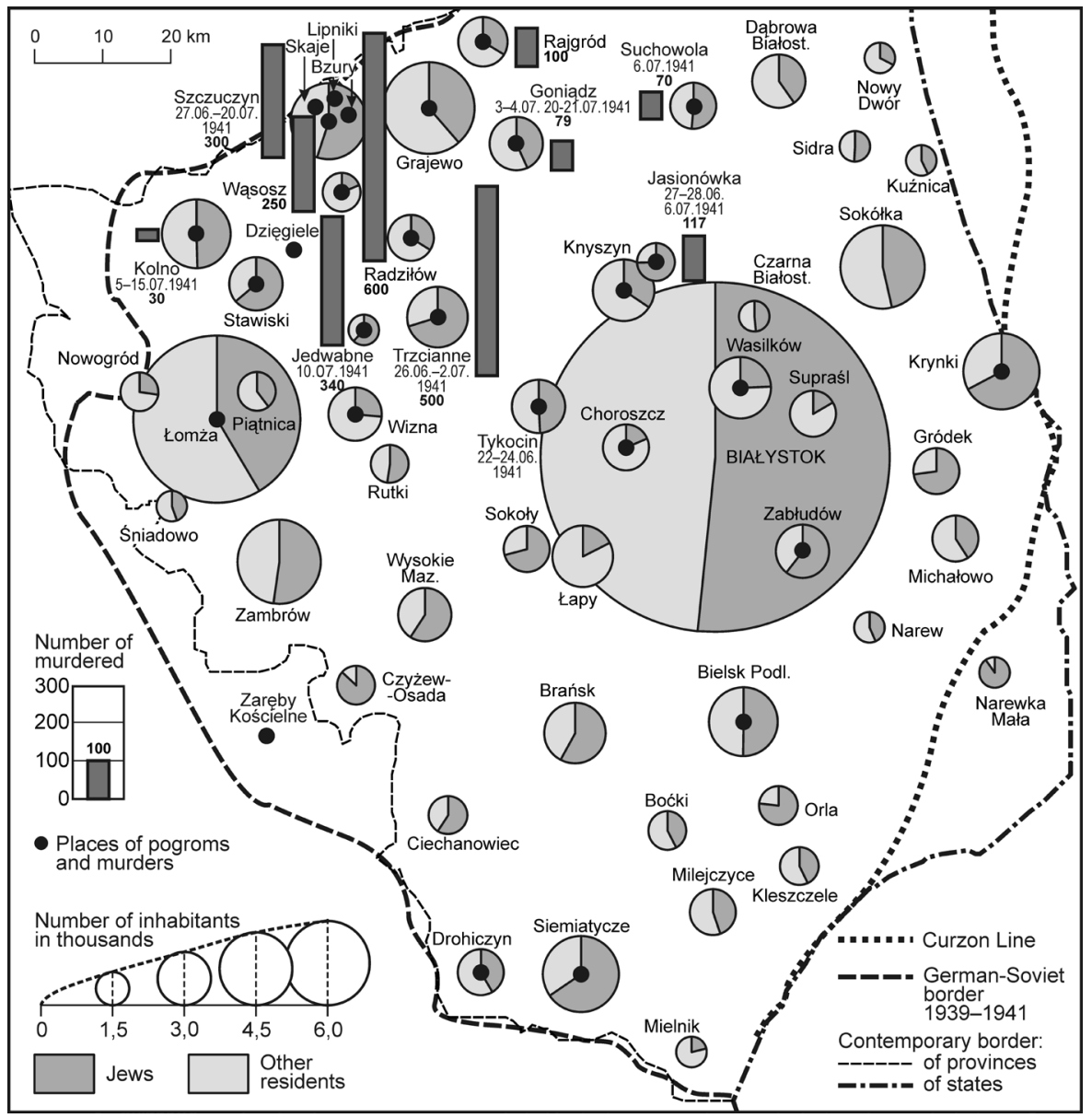

Fig. 6. The share of the Jewish population in the population of selected towns in Podlasie and eastern Mazovia in the late 1930s and early 1940s and selected locations of mass murders of Jews committed by Polish Christians in this area in June and July 1941

Source: own work based on Urynowicz, 2002; Żbikowski, 2002, 2006; Rykała, 2018; Rykała, Wosiak, 2019.

The catalyst of this explosion of collective violence were the pacification activities of the relatively small German police forces behind the eastwards-moving frontline (see more: Dmitrów, 2002, pp. 273-352). However, according to A. Żbikowski (2006, pp. 236-239), they did not determine its cause, just as the experience gained by the Polish society during the nearly two years of Soviet occupation had little to do with the escalation of anti-Jewish sentiments ${ }^{7}$. Pogroms

\footnotetext{
${ }^{7}$ Some individual events, however, had to be so important that they were included in the "anti-Semitic-oriented system of social notions" and generalised in the collective consciousness (Żbikowski, 1992, p. 7).
} 
were first and foremost an explosion of antagonism, mainly economic, that had been brewing for several decades, fuelled by anti-Semitic ideologues, largely originating from nationalist groups, but also from the leaders of the Catholic Church (Żbikowski, 2006, pp. 236-239; Tryczyk, 2015, pp. 50-56; Rykała and Wosiak, 2019 , p. 560). Although Nazi inspiration contributed to their outbreak in the summer of 1941, it was not of primary importance. Although German operational groups - which utilised, as S. Datner (1966, p. 19) has stressed, on their lowest instincts - sometimes initiated outbursts of "people's wrath", supplying weapons and giving instructions, they themselves did not "participate in the slaughter". The stationing of German forces (army and police) was very conducive to the escalation of aggression against Jews but differed significantly from the methodical incidents of August and September of the same year, which assumed the character of genocidal "actions" (Żbikowski, 2006, pp. 238, 222-224).

The scale of the participation of each group of the perpetrators (the local population on the one hand, and the representatives of the occupying German authorities on the other) in a series of acts of collective violence was determined locally, demonstrating a dependence on the location of anti-Jewish terror.

One of the many cases of the explosion of collective anti-Jewish aggression, certainly the most thoroughly investigated, was the pogrom in Jedwabne, which occurred on 10 July 1941. In the presence of a handful of German soldiers, who were involved in helping to catch Jews, Polish neighbours forced the latter onto the market square, where they proceeded to beat them up (as a result of which several died) and forced them to carry out cleaning works. Then they gathered at least 300 of them in a barn and they set it on fire (Datner, 1966, p. 22; Wroniszewscy, 1988, p. 8-9; Żbikowski, 1992, pp. 15-16; Dmitrów, 2002, pp. 332-352; more on this subject in: Gross, 2000; Bikont, 2004).

A few days earlier, on 5 July 1941, a pogrom was conducted in Wąsosz, inspired by Nazis, although conducted by Poles, mainly recruited members of the auxiliary police. During this event, many Jews were injured using primitive tools (axes or pitchforks). As a result, almost the entire local Jewish population (about 250 people) was murdered (Datner, 1966, p. 22; Żbikowski, 2002, pp. 169-172; Milewski, 2002, pp. 87-112; Dmitrów, 2002, pp. 331-352; Monkiewicz, 1989, p. 346).

The local population, hand-in-hand with peasants from nearby villages (Czerwone and Zabiele), with the participation of Nazis, started a pogrom in Kolno (Fig. 6). First, the closest and more distant neighbours forced Jews to perform humiliating cleaning work and raped Jewish women, and then (on 5 July 1941), under the supervision of Nazi police, they organised a humiliating staging, which consisted in forcing Jews to enact a "funeral" of a Lenin statue. The conclusion of the pogrom, during which many houses were robbed and the synagogue burned down, was the murder of about 30 Jewish residents of the town (Datner, 1966, p. 22; Mędykowski, 2012, pp. 262-268; Żbikowski, 2002, pp. 167-168; Dmitrów, 2002, p. 316). 
After Wąsosz and Kolno, the wave of anti-Jewish terror very quickly reached Radziłów (7 July). In a three-day pogrom, Jews were first humiliated and abused. Initially, the richest, mainly shopkeepers living in the market square, were expelled from their homes. They were ordered to clean the market (by pulling out the grass) with cutlery. Numerous rapes were committed - "When there was a beautiful Jewish woman, rape was the first thing to do. (...) They were horrifying, these days before the fire, the expulsion to the market, the beating, the rapes..." (Tryczyk, 2020, p. 13). In the last phase of abuse, local Poles, taking advantage of the permission of Nazi military policemen, forced most of their Jewish neighbours into a barn and burned them there. The remaining ones were caught and killed in other ways. It is estimated that 600 Jews were murdered at that time (Datner, 1966, p. 22; Żbikowski, 2002, pp. 231-259; Milewski, 2002, pp. 87-112; Dmitrów, 2002, pp. 320-322, 332-352; Monkiewicz, 1989, p. 346).

The mass murders or executions of individual people took place in almost all Jewish communities in Podlasie and the eastern part of Mazovia (Datner, 1966, p. 21). The Nazi presence, which enabled the deluge of collective violence against Jews, was significantly different, as I have already mentioned, from the systemic, genocidal activities of August and September 1941. Still, in August the Polish killers resurfaced in, e.g. Szczuczyn. After the pogrom in this town on 27 June of the same year, in which, with the permission of the Nazi army and indifference from the clergy, about 300 Jews were murdered (Żbikowski, 2002, pp. 172-180; Monkiewicz, 1989 , pp. 345-346). The owners of nearby farms came to the local ghetto ${ }^{8}$, with a population of 2,000 people, to hire 80 young Jewish women for work. A group of men came from Szczuczyn to nearby Bzury, where 20 of them found employment in the Zofiówka estate, and kidnapped the women from the fields. After taking the Jewish women to a forest, these individuals raped and killed them with wooden clubs with iron spikes (Datner, 1966, p. 20; Żbikowski, 2002, pp. 178-180; Tryczyk, 2015, pp. 328-332; see also: Domanowska, 2012; Kącki, 2016; Chołodowski, 2017).

After the murder in Jedwabne became public, mainly because of J.T. Gross's book Neighbours: The Destruction of the Jewish Community in Jedwabne, Poland (2000), there occurred a breakthrough in research on the negative attitude of the Polish majority towards the Jewish minority during the war, a topic which had been a taboo. With a nationwide debate ${ }^{9}$ that followed, a plaque commemorating

\footnotetext{
${ }^{8}$ Among those imprisoned in the closed quarter there were mainly women and children because most of the men had been murdered during the pogrom (Datner, 1966, p. 20)

${ }^{9}$ The debate that started was followed by other fundamental works devoted to this subject, e.g.: Wokót Jedwabnego, vol. 1 and 2, edited by Paweł Machcewicz and Krzysztof Persak (2002), My z Jedwabnego by Anna Bikont (2004), U genezy Jedwabnego. Żydzi na Kresach PótnocnoWschodnich II Rzeczypospolitej, wrzesień 1939 - lipiec 1941 by Andrzej Żbikowski (2006). It is worth mentioning that almost a quarter of a century before the publication of Neighbors, i.e. in 1966, the first attempt to break the silence about anti-Jewish violence in July 1941 was made by Szymon Datner in his article Extermination of the Jewish population in the Biatystok District, published in
} 
the murdered Jewish inhabitants of the town was changed. The previous inscription, which falsified the course of events ("The site of the slaughter of the Jewish population. The Gestapo and the Nazi gendarmerie burned 1,600 people alive on 10 July 1941") was replaced for the unveiling of the new monument with a sentence: "To the memory of Jews from Jedwabne and the surrounding area, men, women, and children, fellow inhabitants of this land, who were murdered and burned alive on this spot on 10 July 1941. Jedwabne, 10 July 2001" (Fig. 7). The full truth about the pogrom, especially about its main perpetrators, has still to be set in the stone depicting the burnt doors of the barn in Jedwabne.

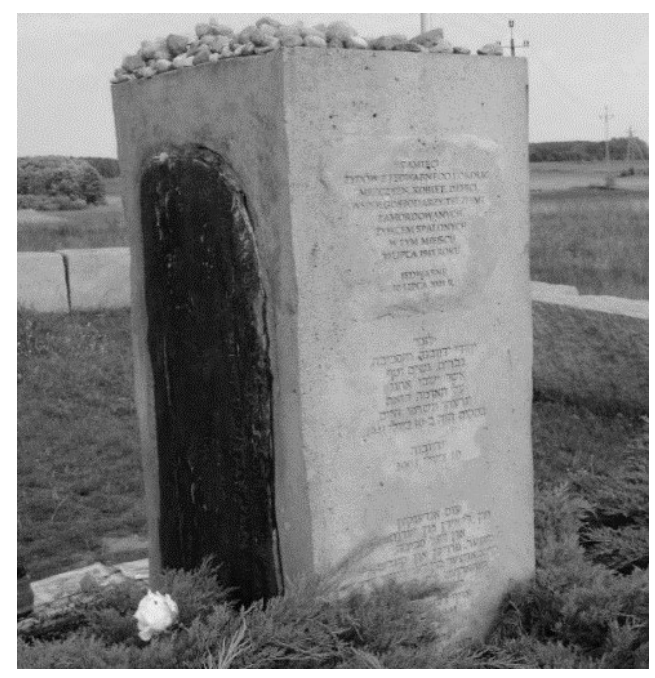

Fig. 7. The monument commemorating Jews murdered (burned) in Jedwabne by their Polish neighbours

Source: own archive (2018).

However, no information about the murder of almost the entire local Jewish population by Poles can be found in Wąsosz. The plaque placed on the mass grave of the pogrom victims there reads: "Here lie the ashes of 250 Jews, brutally murdered in June 1941. Honour to their memory" (Fig. 8). Despite the lack of courage to reveal the full truth about the course of the dramatic events (especially the ethnic affiliation of their perpetrators), there has been a slight progress regarding the lie visitors to this place were told to during the period of the People's Republic of

the Bulletin of the Jewish Historical Institute. A dozen or so years after the apogee of the discussion caused by Neighbours, books about the origins and course of collective terror in Podlasie and eastern Mazovia were written, among others, by Witold Mędykowski (W cieniu gigantów. Pogromy Żydów 1941 r. w byłej sowieckiej strefie okupacyjnej. Kontekst historyczny, społeczny i kulturowy, 2012) and Mirosław Tryczyk (Miasta śmierci. Sąsiedzkie pogromy Żydów, 2015). 
Poland and even afterwards. Until 1995, when the old monument was removed by the locals, the plaque commemorating the site of the mass murder bore the following inscription: "Here lie the Jews murdered by the Fascists"10.

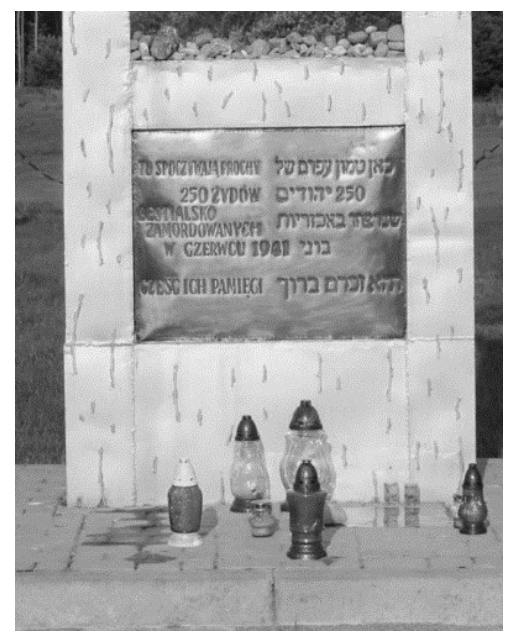

Fig. 8. A plaque on the monument commemorating the burial site of the Jewish victims of the pogrom in Wąsosz

Source: own archive (2018).

Neither has Radziłów become a site of memory the for massacre of 600 Jewish inhabitants by Polish Christians. The monument commemorating their martyrdom still bears an inscription: "In August of 1941, fascists murdered 800 people of Jewish nationality, they burnt 500 of these people in a barn. Honour to their memory" (Fig. 8). In a desperate move triggered by the unchanging position of relevant authorities regarding the information placed on the plaque, in 2011, representatives of the Warsaw Jewish Religious Community set up a plastic plaque of their own authorship to restore the truth about the perpetrators, date and course of the events in Radziłów. The inscription left by this delegation, removed shortly afterwards and replaced with a quotation from John Paul II, stated, among other things, that in this town "from 7 to 9 July 1941 ... about eight hundred Jewish residents were murdered, about five hundred of whom were burned alive in a barn"11. The information also left no doubt as to the ethnic and territorial origin of the perpetrators: "The crime was committed by their Polish brothers - neighbours"12.

\footnotetext{
${ }^{10}$ From the Guide to the commemorated sites of fighting and martyrdom; the years of war 1939-1945, published at the end of the People's Republic of Poland (in 1988), one could learn about Wassosz that "in August 1941, 250 Jews" were shot by Wehrmacht soldiers (Czubryt-Borkowski, 1988, p. 441).

${ }^{11} \mathrm{https}$ ://sztetl.org.pl [accessed on: 18.05.2018]

${ }^{12}$ Ibid.
} 


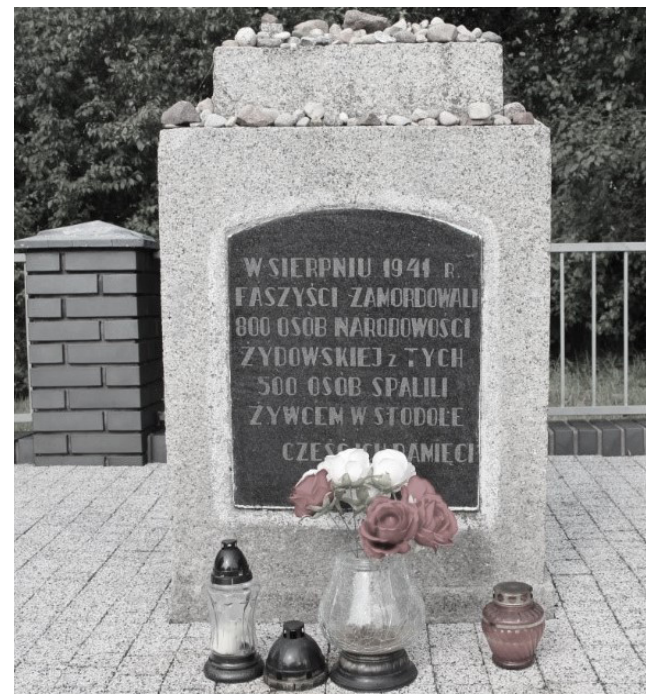

Fig. 9. Monument dedicated to the Jews murdered in Radziłów by their Christian neighbours Source: own archive (2018).

Its counterpart in Szczuczyn is not very far in terms of falsification from the inscription commemorating the Jewish victims in Radziłów. The monument, located on the outskirts of the town, still bears the erroneous information concerning the date of the pogrom, the ethnic origin of the perpetrators and the number of victims: "Here, in $\mathrm{Au}-$ gust 1941, Fascists ruthlessly murdered 600 Jewish people. Honour to their memory".

The murder of young Jewish women in Bzury is slowly being brought back from the abyss of local non-memory. In July 2017, a group of people reached the scene of the pogrom, unable to reconcile with its further tabooing and a failure by competent authorities to attempt to mark it in space. They were led by a witness to those tragic events, eighty-year-old Wojciech P. ${ }^{13}$ Earlier, in June, at the site of the murder Mirosław Tryczyk, philosopher and researcher, set up a grave and was joined by a representation of the House of Memory of the Elder Brothers in the Faith, an organisation co-founded by fr. Wojciech Lemański. On 10 July, through the initiative of a group of people involved in restoring the memory of the place where these dramatic events occurred, a glass plaque with a fragment of Psalm 85 (12) appeared: "Faithfulness springs forth from the earth, and righteousness looks down from heaven..." and the inscription: "Here rests the blessed memory of the Jewish women from Szczuczyn, murdered in the autumn of 1941. May their souls be able to participate in eternal life" (Fig. 10-11).

\footnotetext{
${ }^{13}$ The man, fearing the reaction of his local community, even though almost seventy years have passed since the tragic events, remains anonymous in order, as he says, "not to bring any misfortune upon himself" (Chołodowski, 2017).
} 

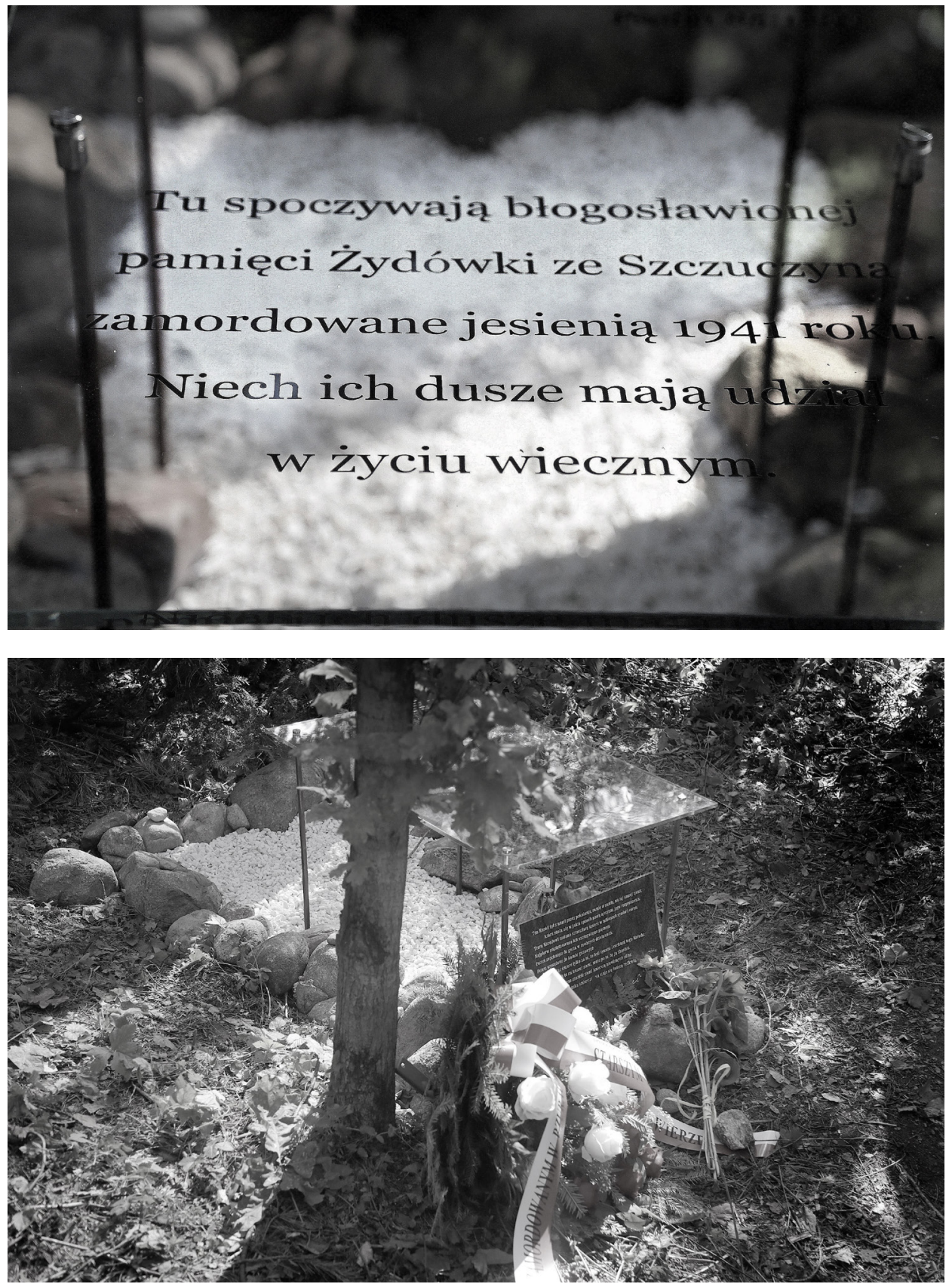

Fig. 10-11. Commemoration (for the first time) on 10 July 2017 of the helpless victims from Bzury at the place of their murder Source: phot. by Agnieszka Sadowska / Agencja Gazeta. 
When considering the issue of anti-Jewish violence from the point of view of places commemorating its victims and perpetrators, the power of the unequal relationship between the majority and the minority appears to be preserved and sanctioned by law. The dominant nation or, to put it differently, the majority of the Polish Nation (all Polish Citizens) imposes on a minority a narration convenient for the former group, using the privilege of deciding on the policies and activities of their subordinate state bodies, including local governments.

The reconstruction of the memory of these places, which could form the basis for the formation of local identity, is used to legitimise the political order established in the name of the national majority ${ }^{14}$.

\section{THE SOCIAL AND POLITICAL CAUSES AND THE SPATIAL CONTEXT OF COLLECTIVE AND INDIVIDUAL ANTI-JEWISH VIOLENCE IN THE PERIOD IMMEDIATELY AFTER THE SECOND WORLD WAR}

Acts of anti-Jewish violence, many of which are still not commemorated in public space with at least the basic truth about their course, were progressing gradually, as was mentioned, along with the liberation of subsequent lands from Nazi occupation. "The massacres, especially common in the Lublin and Rzeszów voivodeships, are moving (...) - as pointed out by the Office for the Aid of the Jewish People ${ }^{15}$ in April 1945 - to other voivodeships like Kielce and Łódź"16.

One of the main sources of anti-Semitic violence was the return of survivors to their pre-war homes. This natural reflex had many reasons, e.g. a longing for their family homes, the desire to regain their possessions, or to learn about the fates of their family members and other relatives. However, many of the returnees could not cross the threshold of their apartments as they had been taken over by their non-Jewish neighbours. A significant part of the assets belonging to the survivors fell into Polish hands even during the war, including items seized "for the most part" as a result of "robbery when transporting Jews to death camps" or given in

\footnotetext{
${ }^{14}$ The main state body initiating and coordinating the works to commemorate historical events, places and figures in the history of the struggle and martyrdom of the Polish nation both domestically and abroad, as well as the sites of the struggle and martyrdom of other national groups on Polish territory between 1917 and 1990 is the Institute of National Memory (IPN) - Commission for the Prosecution of Crimes against the Polish Nation.

${ }^{15}$ The Agency, created through the decision of the Polish authorities on 8 August 1944 in Lublin, operated at the Cabinet of the Council of Ministers.

${ }^{16}$ AAN, Office of the Council of Ministers (URM), Executive Office (BP), ref. 5/17. The tenth report (for April 1945) on the activities of the Department for Jewish Aid at the Ministry of Labour and Social Welfare.
} 
trust for safekeeping ${ }^{17}$. Faced with the impossibility of recovering stolen property, the Jews usually left their pre-war homes, very often forced to do so by local communities, to go to places where members of their families stayed or where larger Jewish communities formed. The hostile attitude towards the previous owners, manifested by the new, unlawful tenants, also created conflict situations. Those often became extremely dangerous, taking the form of ruthless attacks on Jews, some of which ended in fatalities (Gross, 2008, pp. 84-92; Skibińska, 2011, pp. 40-41, 63; Rykała, 2020, p. 45).

Kazimierz Wyka (1945) touched upon the poignant theme of Poles seizing their Jewish neighbours' property and the repercussions of this lawlessness for the survivors:

(...) we found a whole social stratum in the country - the newly born Polish bourgeoisie - which replaced the murdered Jews, often literally, and which, perhaps feeling the smell of blood on its fingers, hates Jews more than ever.

Anti-Jewish sentiments were intensifying against a backdrop of the cases of confiscation and looting of Jewish property, for which their rightful owners or their relatives returned. Those sentiments were strongly rooted in a system of mutual relations that lasted several hundred years, especially economic antagonism (inspired by anti-Semitic ideologues, largely derived from nationalist parties and the leaders of the Roman Catholic $\mathrm{Church}^{18}$ ) strengthened by the occupying forces' racist legislation, which excluded Jews not only from the Polish national community, but also from the human one. The Second World War did not contribute in the slightest to softening or discrediting Poles' prejudices against Jews. Anti-Jewish stereotypes proved permanent. They prevented any sympathy in the Polish society for the victims of the Shoah, and they prevented a sense of solidarity with them (Skibińska, 2011, pp. 4041). Some Poles considered the "extermination of Jews" to be "quite natural", which was a continuation of the "implanted" [during the occupation - author] values and concepts (Hurwic-Nowakowska, 1996, p. 140). The lives of the survivors after the war "meant in many spheres relieving the period of occupation". They still "felt excluded, harassed, discriminated against, unwanted, and even hated." (Skibińska, 2011, pp. 40-41, 69). The continuation of the actions of war-time murderers could be seen in the aforementioned looting of the property of the victims ${ }^{19}$. The killing of a Jew, in the opinion of many Poles, "did not have the significance of murder" (Keff,

\footnotetext{
${ }^{17}$ AAN, Central Committee of the Polish Workers' Party (KC PPR), Secretariat, ref. 295/VII/149. A letter from an anonymous Jew sent by the Warsaw Provincial Committee to the Secretary General of the Central Committee (KC PPR), comrade Wiesław, 25 August 1946.

${ }^{18}$ More on the "experiences of the Catholic Church with Jews and the Holocaust" in J. Leociak, Młyny boże. Zapiski o Kościele i Zagładzie, Wołowiec 2018.

${ }^{19}$ In spite of the extremely difficult material situation of Jews, the myth of their inexhaustible wealth, which was an additional motivation for armed aggressions against them, kept reemerging.
} 
2013, p. 200). Survivors of the Holocaust died "for no apparent reason, only because they were still considered outlawed" (Cała, 2000, p. 169).

Most of the murders occurred in small towns or villages. Combined with the escape of Jews who did not want to share the fate of the victims, these incidents led, especially in eastern Poland, to the disappearance of many Jewish communities (Rykała, 2018, p. 109; 2019, p. 412).

Terror from the Polish environment led, among other things, to the disappearance of Trzcianne, where 13 Jewish people (two families) were attacked on 15 April 1945, from the map of Jewish communities. The victims were then transported "on carts" about $2 \mathrm{~km}$ from Kałuszyn, where three bandits shot three members of the Żutkiewicz family: Ephraim (father, aged 45), Chaim (son, aged 16) and Golda (daughter, aged 9) ${ }^{20}$. Due to a "proclamation ... of the 'Polish Anti-Communist Military Organisation' ordering Jews to leave the settlement of Piaski within 7 days and threatening them with 'appropriate' measures, they ['the few Jews scattered there' - author] were forced to leave this town." 21 "Having rushed to liquidate their personal affairs", the whole Jewish community (of about 200 people) also left Parczew. This was a response to the terror committed in this town on 5 February 1946 by "a uniformed band of assailants (i.e. soldiers of the anti-communist underground), who murdered three local Jews."22

Another reason for the terror was a positive response to the idea proclaimed by a part of the so-called independence underground to fight against "Judeo-Communism" - a stereotype (and conspiracy theory) that was alive throughout the inter-war period, and which was "defrosted" with varying degrees of intensity also during the occupation period (Gross, 2008, pp. 245-263, 268-296; Skibińska, 2011, pp. 66-68; Żbikowski, 2011, pp. 71-73, 79-87; Tokarska-Bakir, 2012, pp. 124 133; Keff, 2013, p. 200) ${ }^{23}$. The origins of the alleged association between Jews and communism lied in the involvement of a part of their political representation in the fulfilment of the idea of a world proletariat, which was to lead to the formation of a new social class, free from all forms of discrimination. A large and disadvantaged minority, additionally deprived of support from their so-called foreign homeland,

\footnotetext{
${ }^{20}$ AŻIH, CKŻP, CKS, ref. 303/XVIII/25. Information about an attack on Jews in Trzcianne.

${ }^{21}$ AAN, URM, BP, ref. 5/17. The tenth report (for April 1945) on the activities of the Department for Jewish Aid at the Ministry of Labour and Social Welfare.

${ }^{22}$ AAN, MAP, DP, WN, ref. 787. The memorial of the Provincial Jewish Committee in Lublin of 23 March 1946 concerning the safety of life and property of Jews; AAN, MAP, DP, WN, ref. 786. A copy of the protocol drawn up on 8 February 1946 by WKŻ in Lublin; more on this murder in, e.g.: M. Bechta, Pogrom czy odwet? Akcja zbrojna Zrzeszenia „,Wolność i Niezawistość” w Parczewie 5 lutego 1946 r., Warsaw 2015; see also a review of this book: A. Grabski, 'Antysemicki pogrom jako kolejne polskie powstanie? Na marginesie pracy o pogromie w Parczewie w 1946 r.', Kwartalnik Historii Żydów 2016, 2, pp. 550-557.

${ }^{23}$ More on the connections between Jews and this political and economic ideology, in, e.g.: Grabski (2004, 2007), Nalewajko-Kulikov (2009), Śpiewak (2012), Kendziorek (2016).
} 
which other groups of this status could count on, was almost organically connected by many people with communism in the Second Republic of Poland. This happened despite it being a culturally and politically diverse community, largely composed of religious or socialist groups opposed to communism (such as Bund, striving for a national and cultural autonomy for Jews in their countries of residence), and persecuted by the system with particular ferocity. After the war, this stereotype was reborn as Jews were allowed to serve in the state administration for the first time in the history of Poland. Due to this social promotion, the affirmative attitude of a part of the Jewish community for the systemic changes in Poland was used (under the banner of fighting "Judeo-Communism") by the anti-communist underground to initiate armed assaults against Jews. Accusations of widespread support for the authorities that lacked social legitimacy, combined with their alleged active participation in the creation of their structures, permeated the wider public. A fertile ground for this type of thinking was created even before the Second World War by the aggressive anti-Jewish activities and agitation of extreme nationalist groups, which were accompanied by a large part of Catholic clergy and press (Rykała, 2018, p. 110; 2020, pp. 54-56; Keff, 2013, p. 204; Kopciowski, 2007, p. 188).

Attacks on Jews were largely initiated by the heirs of the ideology of the nationalist camp, organised in the anti-communist underground. One of them, the National Armed Forces (NSZ), already during the war (in 1942) expressed its position on the dying nation and Poles showing courage to help it in a quite clear way: "Those who want to hide Jews among themselves should be stigmatised and declared traitors of the Polish cause. When every Pole knows that there is no place in the revived Poland, neither for the German nor for the Jew" (in: Grabowski, 2008, p. 88) ${ }^{24}$. Also some members of the post-Home Army underground saw Poland as free of Jews. The leaflet distributed by Freedom and Independence (WiN) contained such seemingly rhetorical questions: "Poles! Do you want the occupation of Poland to continue? (...) Do you want the Polish intelligentsia to be replaced by Jews? Do you want the Polish worker to be a slave to Soviet-Communist-Jewish authorities?" (in: Cała, Datner-Śpiewak, 1997, p. 36) ${ }^{25}$.

The Nationality Department of the Political Department of the Ministry of Public Administration (MAP) reported that from the beginning of October 1945 until the end of that year " 38 Jews were killed by NSZ bandits (...)"26 Apart from murder, other forms of terror were used to free the towns liberated from Nazis from Jewish people. In Radom, among others, in August 1945, "Anonymous members of the Home Army sent out threatening letters to Jews to leave the town and its surround-

\footnotetext{
${ }^{24}$ Extract from the text of "Propaganda Centralna", an organ of the NSZ.

${ }^{25}$ The WiN leaflet was distributed in the run-up to the June referendum in 1946.

${ }^{26}$ AAN, MAP, DP, WN, ref. 786. Report of the MAP's Political Department's Nationality Department for the period: 1 October 1945 - 1 January 1946.
} 
ings, which caused panic among the Jewish population (...)"27 As a result of the departure of many people, the local Jewish Committee ${ }^{28}$ "was dismantled"29.

Jews were relatively rarely killed for purely political reasons, i.e. in order to prevent them from taking positions in various ministries of communist power (especially power ministries) (Cała, 2000, pp. 167-180; Żbikowski, 2011, pp. 79-80; Bańkowska et al., 2009, p. 356) ${ }^{30}$. The crimes motivated by a desire to crack down on individuals perpetuating the new system, were, as can be inferred, committed on specific individuals (Skibińska, 2007, p. 570; Żbikowski, 2011, pp. 79-80; see also: Engel, 1998). More often, when the purpose of violence was robbery or aversion to Jews motivated by the so-called traditional anti-Semitism, those serving the authorities were accidental casualties.

The fight against "Judeo-Communism" was for some of the anti-Communist underground a universal call to purge Polish territories of Jews, which would be enacted by murdering them or forcing them to emigrate. The sentiment was shared by the unlawful owners of Jewish property, guilty of crimes against the rightful owners. Thus, they gained an alibi for their conduct and apparently calmed their unclean consciences (Rykała, 2018, p. 111; 2020, p. 56) (1) $^{31}$

Anti-Jewish violence was also committed by representatives of uniformed services (militia, Security Office, Polish Army), obliged to prevent it. In February 1945, the Office for Aid to the Jewish Population reported that in Dęblin "the police (...) not only does not take part in defending Jews against the attacks that take place, but on the contrary, it itself plays an active part in persecuting the Jewish population." ${ }^{32}$ A month earlier, the commander of the local police denied prewar Jewish residents of the town the right to stay there as they returned from the camp in Częstochowa citing the lack of an appropriate "permit from Lublin." ${ }^{33}$ In Rzeszów, during a "staged «ritual murder»", the police beat up numerous arrested

\footnotetext{
${ }^{27}$ AŻIH, CKŻP, PiS, 303/I/7. Minutes of the meeting of the CKŻP Plenary, held on 14 August 1945.

${ }^{28}$ Jewish Committees (provincial, district and municipal) were field branches of the Central Committee of Jews in Poland, established on 29 October 1944 - the largest organisation of Holocaust survivors, having almost exclusive rights to represent them in relations with the Polish government and the so-called foreigners.

${ }^{29}$ AŻIH, CKŻP, PiS, 303/I/9. Minutes of the meeting of the CKŻP Plenary, held on 31 August 1945. ${ }^{30}$ AAN, MAP, DP, WN, ref. 787. The memorial of the Provincial Jewish Committee in Lublin of 23 March 1946 concerning the safety of life and property of Polish Jews.

31 "There were incidents where the bandits ['NSZ' - author] massacred and robbed Jews and ordered them to leave their homes within 24 hours. In one case, after the murder of Jews, some of the inhabitants robbed their apartments". AAN, MAP, DP, WN, ref. 786. Report of the MAP's Political Department's Nationality Department for the period: 1 October 1945 - 1 January 1946.

${ }^{32}$ AAN, URM, BP, ref. 5/17, Eighth Report (for February 1945) of the Office for Aid for Jewish Population for Edward Osóbka-Morawski, Prime Minister of the Provisional Government of the Republic of Poland.

${ }^{33}$ AAN, MAP, DP, WN, ref. 787. Report of the CKŻP sent on 30 January 1945 to the Voivodship Office in Lublin by WN DP MAP.
} 
Jewish residents, while the Railway Protection Service ordered the imprisonment of those who sought refuge in Krakow and Tarnów ${ }^{34}$ in order to avoid aggression from the inhabitants of Rzeszów. In the same month, police officers in Starachowice demonstrated complete indifference to an act of anti-Jewish terror. Despite the sounds of gunshots fired during an attack on an apartment where eight Jews were staying (two died as a result of the attack) they did not intervene ${ }^{35}$. In Bytom "Public Security Officers from Chorzów were conducting personal searches [among Jewish residents - author] in the street and at the gates in broad daylight, taking away whatever they had." ${ }^{36}$ Strong anti-Semitic prejudices among the officers of the power ministries, especially at lower levels, reflecting the attitude towards the Jewish population of the general Polish society, strengthened the conviction about the participation in the alleged plans of "Judeo-Communism" to seize power in Poland (Żbikowski, 2006, p. 243). Such a conviction was shared, among others, by a member of the Provincial Committee of the Polish Workers' Party (KW PPR) in Legnica, who stated that "Jews will have to leave Poland because their presence in the country makes it difficult to fight the reaction." ${ }^{37}$

In the services established to ensure order and security, and at the same time responsible in a particular way for the consolidation of the new system, the ideological heirs of the nationalist camp, including those burdened with crimes committed against Jews during the war, and even former police officers of the Polish General Government, often found refuge (Skibińska, 2007, p. 573; Tokarska-Bakir, 2018b, pp. 4-6; 2018, pp. 321-405, 409-413) ${ }^{38}$. For example, the police commander in Zwoleń, who had a negative attitude towards Jews, used to be the "vice-presi-

\footnotetext{
${ }^{34}$ AAN, URM, BP, ref. 5/17. The twelfth report (for June 1945) on the activities of the Office for Aid for Jewish Population at the Ministry of Labour and Social Welfare; AŻIH, CKŻP, PiS, 303/I/7. Minutes of the meeting of the Presidium of the CKŻP held on 19 June 1945; Minutes of the meeting of the Presidium of the CKŻP held on 29 June 1945.

${ }^{35}$ AAN, URM, BP, ref. 5/17. The twelfth report (for June 1945) on the activities of the Office for Aid for Jewish Population at the Ministry of Labour and Social Welfare.

${ }^{36}$ AAN, MAP, DP, WN, ref. 787. Copy of a letter from WKŻ in Katowice sent on 18 December 1945 to the Provincial Public Security Office concerning acts of anti-Semitism in the Śląsko-Dąbrowskie Province.

${ }^{37}$ AAN, KC PPR, Secretariat, ref. 295/VII/149. J. Gitler-Barski's letter to CK PPR about plans of Jewish settlement in Lower Silesia, 12 September 1945.

${ }^{38}$ More about the participation of the officers of the power ministries in post-war anti-Jewish violence in the context of the analysis of social conditions of the causes of the Kielce pogrom in the Polish capital: J. Tokarska-Bakir, 2018a. Although this largest act of anti-Semitic crime after the war, which occurred on 4 July 1946, exceeds the scope of the deliberations undertaken in this article, it is worth mentioning that in Kielce, the only group that did not have its representatives in the Provincial Command of the MO were Jews. However, police (MO) members included, among others, officers of the Home Army, Peasant Battalions (BCh), NSZ, "Blue Policemen", Volksdeutsche, Gestapo agents, Schutz- and Hilfspolizei officers [operating in the Third Reich and the General Government, respectively, as Preventive Police and Auxiliary Police - author], and even a pretty high-ranking shmaltsovnik (Tokarska-Bakir, 2018, pp. 4-6).
} 
dent of the local National Democracy" before the war, known for its anti-Semitic views $^{39}$, while in one of the communes in the Jasło district, an officer of the MO was a former Blue Police member "who caught (...) the hiding Jews on his own and liquidated them, stealing their property." 40

The participation of the representatives of power ministries in the violence against the Jewish population contradicted the common belief that Jews were in a privileged position in the new system and that they dominated positions in the power apparatus ${ }^{41}$. This is also confirmed by examples of negative attitude to this minority among local administration officials of all levels (Adelson, 1993, p. 402; Pisarski, 1997, p. 30; Gross, pp. 70-77; J. Tokarska-Bakir, 2012, pp. 133-141). This was most often expressed in the multitude of difficulties in granting apartments (which in many cases were owned by people who applied for them) and the reluctance to employ them in state offices and enterprises. Jews who returned in February 1945 to Dęblin (the Irena district to be precise) and who applied for the allocation of apartments were refused residence permits by the local authorities and the police, who indicated three other towns which were the only ones able to accept them (Lublin, Włodawa, and Żelechów) ${ }^{42}$. At the same time in Krzczonów there were frequent "street round-ups for work only for Jews"43. In Ostrowiec Świętokrzyski, the chairman of the City Council regularly refused to accept a delegation of representatives of the local Jewish community, and their applications were usually dismissed. He even went as far as not to give Jews, who were in an extremely difficult material or psychological situation, bread rations for December 1945, although at the same time he did not deny the inhabitants of Polish nationality such an allocation ${ }^{44}$. The rationing vouchers also became a sign of

${ }^{39}$ AAN, URM, BP, ref. 5/17. Eighth Report (for February 1945) of the Office for Aid for Jewish Population for Edward Osóbka-Morawski, Prime Minister of the Provisional Government of the Republic of Poland.

${ }^{40}$ AAN, MAP, DP, WN, ref. 786. Copies of reports of some murders and robberies conducted against the Polish Jewish population.

${ }^{41}$ The fact that Jews or people of Jewish descent (after all, it is a matter of self-determination) joined the UB [the secret police], MO [regular police] and the army resulted from various, often complex motivations. The need to oppose forces hostile to the new political order as an expression of an acceptance of the political changes taking place in Poland was one of them. The survivors were also pushed to work in law enforcement by a sense of threat from the non-Jewish environment. In addition to a kind of shelter, these services provided an opportunity to influence the course of events in the country and facilitated access to legal weapons, useful in the face of attacks. Among the reasons for joining the ranks of these services, one cannot exclude the natural desire for exacting a reckoning on those guilty of humiliation, harm and crime, or even to bring about some form of compensation or revenge (Skibińska, 2007, p. 572; see also: Kainer, 1983; Kersten, 1992, 1993; Paczkowski, 2001; Libionka, 2006). ${ }^{42}$ AAN, URM, BP, ref. 5/17, Eighth Report (for February 1945) of the Office for Aid for Jewish Population for Edward Osóbka-Morawski, the Prime Minister of the Provisional Government of the Republic of Poland.

${ }^{43}$ Ibid.

${ }^{44}$ Ibid. 
discrimination against the Jewish community in Łuków. The head of the local food supply department did not agree to distributing category I food vouchers to Holocaust survivors because of their alleged reluctance to work ${ }^{45}$.

Then, "in Jędrzejów, the starost (...) refuses all Jewish affairs, as in Chęciny and Chmielnik. In Ostrowiec, the National Municipal Council demanded [from the local Jewish committee - author] to send all Jews to work in the mine." ${ }^{46}$ The starost of Radom was "hostile towards citizens of Jewish nationality". He consistently refused to receive their delegation, which was concerned about the dissemination of leaflets with anti-Semitic sentiments in places under his administrative authority ${ }^{47}$. In Tarnów, the Municipal Council collected tax arrears from Jewish residents "from the time of the German occupation, i.e. from the time when the above-mentioned people were in German concentration camps and their property was under German administration." ${ }^{48}$ The ruthless behaviour of local government officials and public security officials was often accompanied by verbal aggression and incitement to relocate ${ }^{49}$.

In their attempt to achieve justice, Jews could rarely count on the authorities obliged to ensure it. During criminal proceedings against Polish citizens accused of crimes against the Jewish minority (both during and after the war) the testimonies of Jewish victims and witnesses were often ridiculed and deprecated. Such an attitude only increased their alienation and confirmed their conviction about the lack of proper support from the state apparatus (Skibińska, 2011, p. 65). The fear of the Jewish population of the scale of the murders was intensified by the impunity of the perpetrators.

Jews were murdered for being Jewish, and for serving in the new authorities; the fact of seizing Jewish property and the intention to prevent survivors from regaining their property were not the only reasons for anti-Jewish violence. Religious superstitions, in particular legends of ritual murders, were an inexhaustible source of prejudice. The medieval version (in which the blood of a murdered nonJew was to be used to make matzah) was joined after the war by its "modernised" - as A. Żbikowski (2011, p. 72) has noted - variant: the blood of Christian children was to be used for transfusions for Jews exhausted by the war.

${ }^{45}$ Ibid.

${ }^{46}$ AAN, MAP, DP, WN, ref. 787, Letter from the Director of the Political Department of MAP to the Provincial Office in Kielce, 25 June 1945.

${ }^{47}$ AAN, MAP, DP, WN, ref. 787. Letter from the Director of the Political Department of MAP to the Provincial Office in Kielce of 30 October 1945, concerning the hostile attitude of the Radom starost towards the Jewish population; Statement of the Radom starost's secretariat, dated 21 January 1946; Statement of Seweryn Kahane, President of the Provincial Jewish Committee in Kielce, and M. Bojm, President of the Regional Jewish Committee in Radom, dated 21 January 1946.

${ }^{48}$ AAN, MAP, DP, WN, ref. 787, a copy of the letter of the District Jewish Committee in Tarnów to the CKŻP on the activities of the Housing and Construction Commission and the army, dated 13 November 1945.

${ }^{49}$ AAN, MAP, DP, WN, ref. 786. Letter from the Political Department of the MAP to seven voivodes, dated 21 March 1945; AŻIH, CKŻP, Organizational Department (WO), ref. 15. Those wanting to settle were threatened by unidentified groups with underground names. 
The use of the legend of a ritual crime (allegedly committed on a little girl) was the basis of one of the first post-war acts of collective violence, which occurred on 12 June 1945 in Rzeszów. The aggression of the crowd directed towards the Jewish population, as well as mass arrests, forced a vast majority of approximately 1,000 local Jews to leave ${ }^{50}$.

\section{SELECTED ACTS OF COLLECTIVE AND INDIVIDUAL MURDERS COMMITTED AGAINST HOLOCAUST SURVIVORS IN THE FIRST MONTHS AFTER THE SECOND WORLD WAR}

Even before the end of the war, in March 1945, 117 Jews were attacked in the areas liberated from Nazi occupation: 21 in the Białystok Voivodeship, 33 in the Lublin Voivodeship, 35 in the Warsaw Voivodeship, 23 in the Rzeszów Voivodeship, and 5 in the Kielce Voivodeship. As a result of these acts of banditry, 108 people were killed and 9 wounded. In April of that year, even though the number of assaults decreased (to 11), 32 people were murdered and 7 wounded $^{51}$. In May, the month when the war ended, there were two assaults and as many deaths in Lublin, while in Łódź there was a mugging and eight fatalities ${ }^{52}$. In the opinion of the director of the Political Department of MAP, expressed in March 1945, "accidents of harassment and even murder" led to "an outstanding deterioration of moods among the Jewish population, pessimism and distrust towards the authorities" ${ }^{\prime 3}$.

On 11 February 1945, after Nazi troops withdrew, a family of three was murdered in the village of Rozalin near Baranów (Fig. 12). The same number of Jews

\footnotetext{
${ }^{50}$ AŻIH, CKŻP, WO, ref. 34; AAN, URM, BP, ref. 5/17. The twelfth report (for June 1945) on the activities of the Office for Aid for Jewish Population at the Ministry of Labour and Social Welfare; AŻIH, CKŻP, PiS, 303/I/7. Minutes of the meeting of the Presidium of the CKŻP held on 19 June 1945; Minutes of the meeting of the Presidium of the CKŻP held on 29 June 1945.

${ }^{51}$ AAN, MAP, DP, WN, ref. 786. Letter of the head of the Social and Political Department of MAP to the Ministry of Public Security, dated 29 September 1945, concerning murders and robberies committed against Polish citizens of Jewish nationality. In the Kielce Voivodeship, in the penultimate month of the war, there were 5 attacks on Jews ( 18 people were killed and 4 wounded), in the Lublin and Warsaw Voivodeships -2 each ( 8 killed in the first one, 4 wounded in the second), while in the Rzeszow (Lviv) and Krakow Voivodeships - 1 each (1 wounded, 2 murdered, respectively). It should be specified that, for example, out of the two attacks in the Warsaw Voivodeship, one was a mugging. Apart from those killed and wounded in the Warsaw Voivodeship, 2 people were abducted and probably murdered.

${ }^{52}$ Ibid. According to the findings of the Political Department of MAP, which do not cover all acts of anti-Jewish violence, between April and August, a total of 31 attacks were conducted, in which 81 Jews were killed, 13 wounded and 2 were abducted.

${ }^{53}$ AAN, MAP, DP, WN, ref. 786, Letter from the Political Department of MAP to seven Voivodes, dated 21 March 1945.
} 
were killed on April 6 of the same year in Kosowo Podlaskie. The murder victims were: Hersz Siedlecki (30), Icek Majdenberg (22), and Gita Jabłkowska (20). Rojza Flam (26) and Lejb Makowski (35) were gravely wounded, while Szloma Wajnstein (34) and Sura Fajgenbaum (54) were abducted ${ }^{54}$.

In the same month, five Jews were murdered in Połaniec near Staszów and as many in Klimontów (in the Sandomierz district). The Połaniec murder, which occurred on 9 April, claimed the lives of two ten-year-old sons of Chuna Berger, Herszl Berger, his sister and sister-in-law. The wounded were: Chuna, his niece, and Berek Berger, his nephew. In Przedbórz, eight people were killed in an anti-Semitic attack on 27 May $1945^{55}$.

In June, the first month with no warfare activities, 2 people were murdered in Częstochowa (on the 1st), with as many killed in Lublin (9th) and Starachowice (14th). The murder of three people of Jewish descent (with at least 50 people injured and severely beaten) occurred in Działoszyce (on the night of 16 June). The next three are the balance of murders committed by Polish citizens in Przemyśl (18th).

Also three victims were killed in anti-Jewish terror acts in Sanok, which occurred on 12 August. On the 25th of the same month, four Jews were murdered in Skaryszew.

The murder of five Jews in Raciąż on 13 August 1945 was definitely a ruthless act of violence, which, like other, not only frightened those returning to their hometowns, but also made them doubt the prospect of rebuilding their lives in Poland. During two days (16-17 December), one and two, respectively, Jewish citizens died at the hands of Polish citizens (including a Polish Army sergeant) in Bytom ${ }^{56}$.

"It happened in Tarnogród in Biłgoraj County." On 20 December 1945 Chaim Fainer (Szloma's father, who lived in Wrocław), while travelling to Biłgoraj, his hometown, visited a Jewish family in Tarnogród, where he wanted to spend the night. In the apartment, there were Pesa Wachnachter (35), her 9-month-old child and Symcha Sztatfeld, who, according to the testimony of Ojzer Wachnachter, Pesa's husband, left the apartment at that time because of the suspicious behaving Roch Botek, a non-Jew. The call "Where are the Jews here?" forced Wachnachter's neighbour, Ostrowski, to let in the intruders, who proceeded to kill all the Jews present there: Chaim Fainer, Pesa Wachnachter (35) and her nine-month-old child ${ }^{57}$.

\footnotetext{
${ }^{54}$ AAN, MAP, DP, WN, ref. 786, Copies of reports of some murders and robberies conducted against the Polish Jewish population.

${ }^{55}$ Ibid.

${ }^{56}$ AAN, MAP, DP, WN, ref. 786, Copies of the reports of some murders and robberies carried out on the Polish Jewish population; AAN, MAP, DP, WN, ref. 787. A copy of a letter from WKŻ in Katowice sent on 18 December 1945 to the Provincial Public Security Office concerning acts of anti-Semitism in the Śląsko-Dąbrowskie Province.

${ }^{57}$ AAN, MAP, DP, WN, ref. 787. A report drawn up by an official of the CKŻP N. Blumencwajg, 28 January 1946, based on the testimony of Szloma Fajner. At the Provincial Security Headquarters,
} 
As the months since the end of the war passed, the wave of anti-Semitic violence was not receding. A new wave was triggered by the repatriation of Polish citizens from the USSR. On its brink, in February 1946, there were, among others, murders of three Jews in Myszków $w^{58}$, and the same number in the already mentioned Parczew ${ }^{59}$.

The latter town was surrounded on the $5^{\text {th }}$ of that month by uniformed "assailants in the strength of 100 to 120 men". Armed with firearms, the "gang went wild with impunity" for 5 hours. The partisans of the anti-communist underground slaughtered "defenceless Polish citizens, of Jewish nationality": Mendel Turbiner (31), Abram Zysman (43), Dawid Tempy (42); Lejb Frajberger was wounded. Jewish property did not escape the attention of the attackers. Most of the houses were plundered, and items from them were placed on horse wagons and taken away. "In a number of cases where Jewish property did not represent a business opportunity for the attackers, it was destroyed so that it lost any value." ${ }^{60}$ As a result of this tragic event and the lack of proper reaction from the authorities responsible for their safety, the local Jewish community (about 200 people), "having quickly liquidated their personal affairs, left the town." ${ }^{61}$

There were also individual murders, e.g. in Żarnów (on the night of 10 June 1945), Lublin (17 August), Tokarnia near Chęciny (in August), Bydgoszcz (in September), and Zabrze (19 January 1946) ${ }^{62}$.

Pesa Wachmachter's husband and Sztatfeld reported Botek and Ostrowski as the perpetrators of this deed. Five weeks after the crime, not only no investigation was started, but also a municipal official addressed "the last Jew of this town ... with a request to sign a report that the case for the above murder was discontinued due to lack of evidence."

${ }^{58}$ AAN, MAP, DP, WN, ref. 787. The memorial of the Provincial Jewish Committee in Lublin of 23 March 1946 concerning the safety of life and property of Polish Jews; AAN, MAP, DP, WN, ref. 787. Announcement of WKŻ in Katowice (for CKŻP) on the murders of Jews in Gliwice and Myszków, 4 February 1946. ${ }^{59}$ AAN, MAP, DP, WN, ref. 786. Copy of the minutes drawn up by WKŻ in Lublin, 8 February 1946, concerning the events in Parczew.

${ }^{60}$ AAN, MAP, DP, WN, ref. 787, The memorial of the Provincial Jewish Committee in Lublin of 23 March 1946 concerning the safety of life and property of Polish Jews; AAN, MAP, DP, WN, ref. 786. Copy of the minutes drawn up by WKŻ in Lublin, 8 February 1946, concerning the events in Parczew; more on this murder in, e.g.: M. Bechta, Pogrom czy odwet? Akcja zbrojna Zrzeszenia „Wolność i Niezawisłość” w Parczewie 5 lutego 1946 r., Warsaw, 2015; also see a review of this book: A. Grabski, 'Antysemicki pogrom jako kolejne polskie powstanie? Na marginesie pracy o pogromie w Parczewie w 1946 r.', Kwartalnik Historii Żydów 2016, 2, pp. 550-557.

${ }^{61}$ AAN, MAP, DP, WN, ref. 787. The memorial of the Provincial Jewish Committee in Lublin of 23 March 1946 concerning the safety of life and property of Polish Jews. A. Żbikowski (2006) placed Jews who served in the Volunteer Reserve of Citizens' Militia (ORMO, a paramilitary organization supporting the police) who died in Parczew at the hands of the WiN unit, among accidental casualties. The attack was supposedly organised for primarily ideological reasons (disagreement with the new order) and mugging. ${ }^{62}$ AAN, MAP, DP, WN, ref. 786. Copies of the reports of some murders and robberies conducted against the Polish Jewish population; AAN, MAP, DP, WN, ref. 787. A copy of the report of $23 \mathrm{Ja}-$ nuary 1946 on the murder of a person of Jewish nationality in Zabrze, the state of the investigation, the behaviour of Polish society, the position of municipal and party authorities and the course of the funeral; AAN, KC PPR, Secretariat, ref. 295/VII/149. 


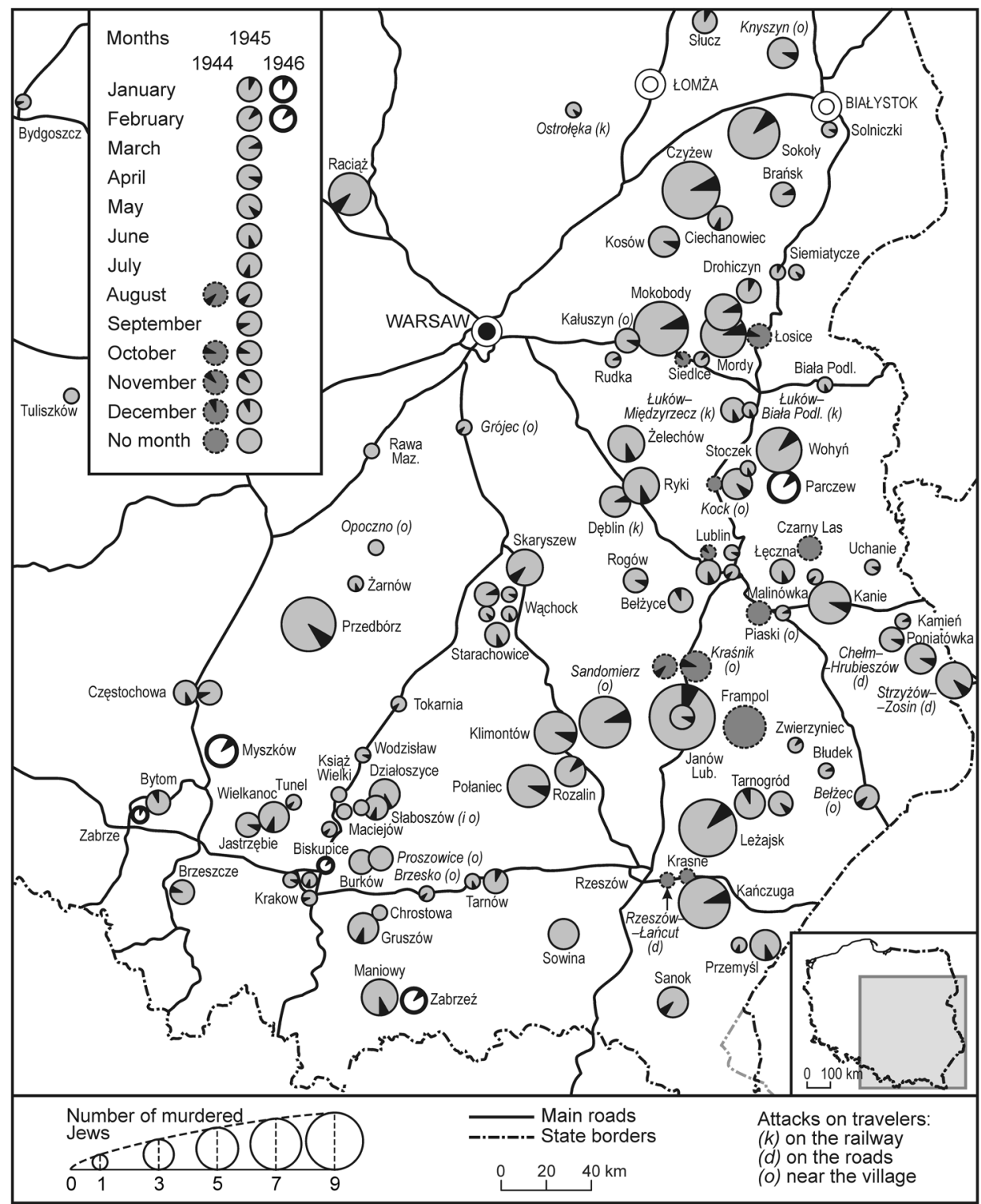

Fig. 12. Selected sites of murders committed by the Polish majority on Jews between late October 1944 and early February 1946

Source: own work based on AAN, MAP, DP, WN, ref. 786, 787, 788; AAN, KC PPR, Secretariat, ref. 295/VII/149; AAN, URM, BP, ref. 5/17; AŻIH, CKŻP, PiS, 303/I/11; Cała, Datner, 1997; Engel, 1998; Żbikowski, 2006, 2011; Skibińska, 2007, 2011; Kopciowski, 2007; Gross, 2008; Bańkowska et al., 2009; Kwiek, 2013; Cała, 2014; Rykała and Wosiak, 2019. 
Acts of terror directed at Holocaust survivors also occurred outside dense settlements, often during the so-called "train actions," conducted by various groups of the armed anti-communist underground. For example, on 30 June 1945, Jakub Magliński and Rywka Staretz were murdered on a train travelling from Łuków to Międzyrzecz, while on 22 August, $4 \mathrm{~km}$ from Belzec, the seat of the recent death camp, 2 people were shot dead and 2 wounded ${ }^{63}$.

"The suppression of German fascism has not yet brought the Polish Jewry the desired peace," the local Provincial Jewish Committee (WKŻ) reported in its memorial devoted to the safety of the Lublin region's Jews ${ }^{64}$. "The Jews who came out of the bunkers, out of the forests, (...) returned from the camps, from exile or emigration, in many cases met with hostile attitudes on the part of Polish society" Deprived of a sense of security due to such an attitude of the national majority, they strived "to cross the border illegally, creating on the other side [in Germany - author], to the amazement of the world, numerous groups of fugitives from Poland" $" 66$.

Violence was also experienced by Jews coming to Poland from the USSR as part of organised, legal repatriation (Fig. 13) who, holding Polish citizenship until 17 September 1939, lived permanently in the lands seized by the Soviet Union (the so-called Eastern Borderlands) and stayed in the central and eastern parts of the Soviet Union (between February and June 1946, 120,579 Jews returned) (Zarys..., 1947, p. 13; Grynberg, 1986, p. 20; Rosner, 2018, pp. 27-29) ${ }^{67}$.

Although the problem of the attitude of the Polish society towards Jewish repatriates exceeds the temporal scope of this analysis, it is worth mentioning that the violence they suffered varied in terms of intensity: from mockery, through harassment and humiliation, to murder. The return to the country occurred in a period of an atmosphere which was described as "pogrom" in the documentation prepared at the time by the Central Committee of Jews in Poland (CKŻP), the largest organisation representing this community (Skibińska, 2011, p. 52).

On 2 February 1946, at the threshold of formal repatriation, which is the end date of this analysis, Zelig Weisberg, a repatriate from the East, was murdered.

(...) around $7 \mathrm{pm}$, the apartment (...) where Kagan Szloma and his 11-year-old son Mojżesz, Kamieniecki Szmul and Weisberg Zelig resided and were present, was broken into by two unknown men (...) in civilian clothes. (...) they searched those present, insulting them and shouting "rotten Jews, what did you come to Poland for" etc., beating and torturing them. (...) After searching the whole apartment, the bandits began to terrorise Weisberg Z., demanding money and valuables from him. When he answered that they had already taken

\footnotetext{
${ }^{63}$ AAN, MAP, DP, WN, ref. 786. Copies of the reports of some murders and robberies conducted against the Polish Jewish population.

${ }^{64}$ AAN, MAP, DP, WN, ref. 787. The memorial of the Provincial Jewish Committee in Lublin of 23 March 1946 concerning the safety of life and property of Polish Jews.

${ }^{65} \mathrm{Ibid}$.

${ }^{66}$ Ibid.

${ }^{67}$ AŻIH, CKŻP, Department of Records and Statistics (WEiS), Ref. 474, 502, 507.
} 
everything he had (...) the older of the bandits fired at Weisberg 6 times, shooting him dead on the spot. Seeing that a similar end awaits the others, they started screaming and making noise. The bandits got scared and ran away $(\ldots)^{68}$.

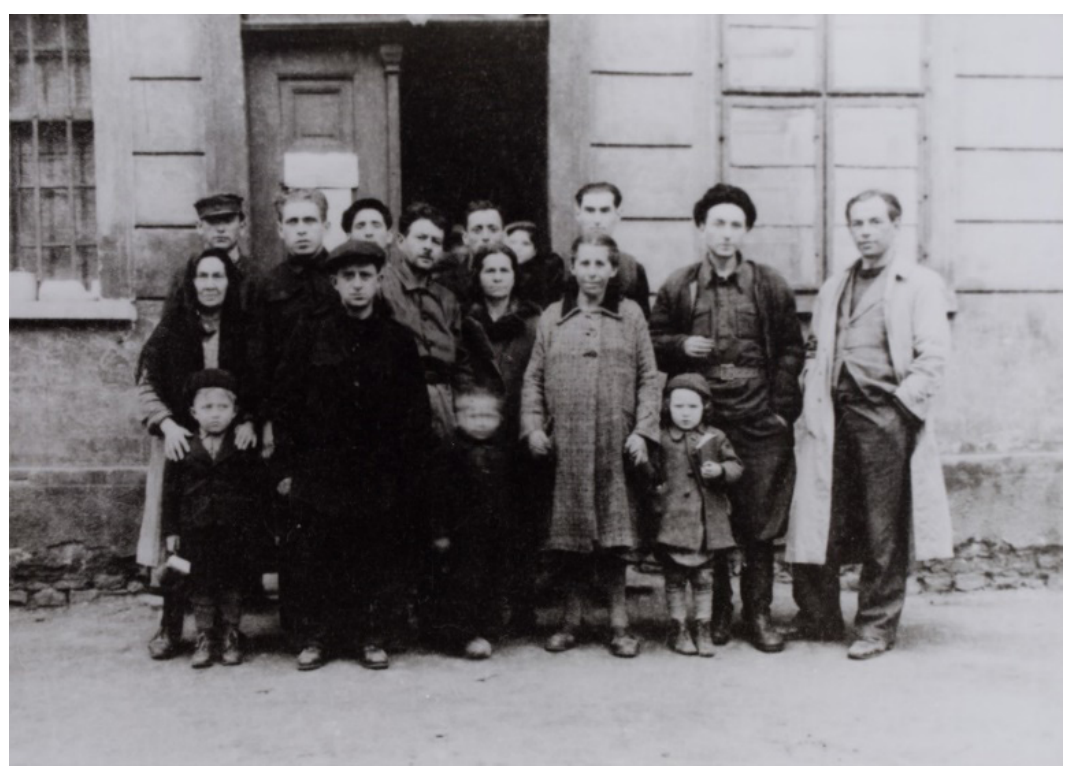

Fig. 13. Jewish repatriates from the USSR in Bielawa in 1946

Source: the collection of E. Ringelblum Jewish Historical Institute in Warsaw.

The "covert murders and organised attacks of armed gangs" ${ }^{69}$ compelled Jews to emigrate: internally - from small towns (with or without a small group of survivors) to larger ones, more secure and thus creating the prospect of achieving relative stability, and externally - outside Poland, continuously since the withdrawal of the occupying Nazi forces (Rykała, 2007, pp. 24, 26). In March 1946, i.e. in the initial phase of legal returns from the Soviet Union, WKŻ in Lublin reported:

The mood of panic among Jews is growing and it is spreading in ever larger circles. Their system of nervous sensitivity, impaired in the years of German hell, during the period of crematoria and gas chambers, causes those Jews who had a basis for existence in the country, based on sound economic and social principles, to abandon their homes and workshops to find themselves outside the area affected by the plague of anti-Semitism ${ }^{70}$.

${ }^{68}$ AAN, MAP, DP, WN, ref. 786. A copy of a letter from the Jewish Committee in Gliwice to the CKŻP, dated 7 February 1946, concerning the murder of Weisberg Zelig.

${ }^{69}$ AAN, URM, BP, ref. 5/17. The tenth report (for April 1945) on the activities of the Department for Jewish Aid at the Ministry of Labour and Social Welfare; AAN, MAP, DP, WN, ref. 786.

${ }^{70}$ AAN, MAP, DP, WN, ref. 787. The memorial of the Provincial Jewish Committee in Lublin of 23 March 1946 concerning the safety of life and property of Polish Jews. 


\section{SITES OF NON-MEMORY, NON-SITES OF MEMORY}

Referring to the estimations of researchers (especially J. Adelson, D. Engel, A. Skibińska, A. Żbikowski, A. Cała, J. T. Gross, A. Bańkowska, A. Jarzębowska, and M. Siek,), when making one's own analysis of cases of murders of Jews, it should be assumed that between 1944 and 1947 at least 1,000 people of Jewish nationality, of all age and gender, lost their lives in this way. It is possible that in 1945 alone, 353 Holocaust survivors died at the hands of Poles (Kopciowski, 2007, p. 205; Skibińska, 2007, p. 568; Żbikowski, 2011, p. 91 ${ }^{71}$. The total number of fatal incidents, in many cases collective murders, oscillated between 200 and 300 (Żbikowski, 2011, p. 93; Skibińska, 2011, pp. 64-65; Cała, 2014, p. 17; Grabski, 2002, p. 73). The vast majority of anti-Jewish events happened in the eastern, south-eastern and central Poland.

Under the influence of these treacherous murders and organised attacks, serving as a continuation of anti-Jewish violence dating back to at least the $1930 \mathrm{~s}$ and reinforced by the occupation's legal system and Hitler's mass anti-Semitic propaganda, an ethnic cleansing was taking place in Poland, as A. Cała (2014, p. 27) claimed. It was "initiated by the deportations conducted by the Nazis, and it concluded with the expulsion of Jews from Poland in 1968" (Cała, 2014, p. 27). Although the postponement of the completion of ethnic cleansing for many years after the war may be controversial, given the different situation of the Jewish population during this global conflict and more than two decades after its end, there is no doubt that under the influence of the brutal state anti-Semitic campaign, which was absorbed by a part of the population and with indifference of the rest, at least 12,000 Jews were forced to leave the country, which led to a radical reduction (by nearly a half) of this minority in Poland ${ }^{72}$.

There have been only few commemorations in public space of the numerous cases of post-war violence against Jews. The establishment of a site of memory $^{73}$ usually happened in relation to those crimes that had the largest number of victims, occurred in large cities, were precisely located and, due to this baggage of characteristics, have been academically described (such as the pogroms

\footnotetext{
${ }^{71}$ In the Lublin region, between the summer of 1944 and September 1946, 118 Jews were murdered, sometimes in combat, in 30 separate incidents (Kopciowski, 2007, p. 205).

${ }^{72}$ After the so-called March emigration wave in 1971 decreased, about 13,500 Jews remained in Poland (Rykała, 2007, p. 209).

${ }^{73}$ Site of memory - a term combining place and memory - is expressed both topographically and symbolically. According to M. Delaperriére (2013, p. 49), it means both a specific topographical point and all material and non-material signs and traces recalling the past in collective memory. In this first sense, a site of memory includes, among others: monuments, commemorative plaques, historical buildings, relics, ruins, museums, and cemeteries. Another way of expressing these places (material and non-material signs and traces) involves the aforementioned symbolic (metaphorical) meaning. Due to the stigma of death or suffering they also remain the places where one is remembered ("sites of recollection").
} 
in Krakow in August 1945 or in Kielce in July 1946). It should be assumed that these at least 200 sites of crimes against Holocaust survivors - the reference to an approximate number shows that a clear figure is impossible to arrive at at this early stage of research - will never be remembered in any form ${ }^{74}$. Topographically speaking, marking the information about acts of terror and their victims seems impossible because of the difficulty in identifying the location of many such incidents. After the war, the areas where they occurred underwent significant changes in development. As a result, not only has the possibility of spatial identification of the traces of crime scenes diminished, but that also applies to the possibility of introducing any elements commemorating it. Potential obstacles include the state of ownership, the type and form of use, and, above all, the willingness of the users to co-exist with these elements. Outside cities, the places in question had a topographical attachment within village boundaries, next to urbanised areas - also on meadows and in forests. Sometimes, they are distinguished in the landscape by some anthropogenic constructions, but there is usually nothing that marks such places: they interfere with buildings, and they are covered with clumps of grasses, bushes and hills.

The form of public commemoration is usually reserved for figures, events and deeds that have a special, momentous dimension for the formation of various spheres of life of such public status. In the system of mutual Polish-Jewish references in the post-war period, the Kielce pogrom gained such a rank - as the largest act of anti-Semitic violence after the Holocaust, which resulted in the emigration of Jews from Poland on an unprecedented scale and, as a consequence, a radical decrease of their share in the general population. This event has become a symbol of Polish prejudice, exclusion, harassment, discrimination, aversion and even hostility towards Jews. In this sense, Kielce, just like Jedwabne for the Second World War period, became a concept and a sign expressing not only this particular town, but a conventional representation of several dozen, several hundred places where Jews were murdered by Poles.

In the possible pursuit of topographical marking of acts of terror, it is also worth considering all those people of non-Jewish origin whose lives were interrupted in similar or other circumstances, although not because of their ethnic (religious) affiliation, and who have not received any form of commemoration. At the root of the problem, however, lies not the rivalry for priority in suffering between Poles and Jews (after all, the latter, despite being aware of their ethnic origin, often identified themselves with Polishness, and their sense of national affinity was subject to gradation), but the will to spark reflection on the salvation of the individualism of all victims, regardless of their descent. In the case of Jews, however, it is a community which, as a result of the Shoah and the consequent emigration, became one

\footnotetext{
${ }^{74}$ Commemoration is opposed to forgetting. Thus, one can point to sites of forgetting, which are topographical anchor point only for a few individuals (who are the only ones that distinguish such points in the landscape, know their character, and sometimes discuss them).
} 
of the least numerous minorities in Poland, and was therefore deprived of a significant power to record in public space the locations of heroic deeds or suffering, or to revitalise already existing markings. In view of the inertia of the relevant state authorities, the effort to achieve this goal, often treated as a kind of moral obligation, has thus largely rested with the representatives of the Jewish community, as well as people ethnically unrelated to it but involved in many ways in nurturing the heritage of Polish Jews, who perceive their Jewish compatriots as an integral part of Polish history, even a component of Polish national identity ${ }^{75}$.

\footnotetext{
${ }^{75}$ The care to restore the memory of places (or larger fragments of space) marked by heroic or traumatic events also consists in preventing the covering, often done as a gesture of commemoration, by another presence. Such efforts are being made, for example, in relation to the area of the former Warsaw Ghetto, as attempts are being made to deprive the site of its significance by implementing a plan to build a monument to the Righteous Among the Nations, honouring Poles who rescued Jews during the Second World War, to be erected next to the Museum of the History of Polish Jews and the Monument of the Ghetto Heroes. The defenders of the inviolability of the memory (and its signs) of the "burnt-out" ghetto space - more and more strongly, thanks to the work of many academic institutions and social organisations, which is recorded both in the imaginary topography and in the form of signs symbolising the dramatic events of the uprising, include the participants of the uprising in the closed district, representatives of Polish Jews, and researchers of Jewish issues. The protesters, while honouring and expressing gratitude to the Polish Righteous, strongly support the idea of erecting a statue to the rescuers, especially since many of them remained anonymous, having to hide from their Polish neighbours because of their unprecedented bravery. Opponents of the deconstruction of this peculiar topography of emptiness in the cultural landscape, driven by a special kind of obligation towards thousands of victims who lived and suffered on this piece of land, who were subjected to unimaginable violations of their dignity, and who, eventually, perished, have made appeals and sent letters to relevant institutions. In 2015, an open letter to the presidents of Poland and Warsaw was sent by Pnina Grynszpan Frymer and Simcha Rotem Ratajzer (pseud. Kazik), who both participated in the Warsaw Ghetto Uprising. They wrote: "We cannot (...) comprehend why this monument should stand in a place where hundreds of thousands of people have died alone, without help, in the vicinity of the monument, which is their symbolic tombstone, a site of memory. (...) We ask you to preserve for them this piece of the former ghetto, to respect the feelings of those who feel they are guardians of their memory. (...) Warsaw is huge. There are certainly many worthy places in Warsaw to remember the Righteous. We solemnly ask for it (Pomnikowi...)." Other open letters, initiating a discussion around the monument, emphasised that "The monument of gratitude to people who saved Jews is to stand among the ashes of those who were not helped and whom no one wanted to help. The fate of the Jews who died in extreme solitude will be lost in this." (Janicka et al., 2014, p. 39). "This symbol [the monument to the Righteous - author] takes away the voice of thousands of existing Jewish testimonies and even more of those that have not been recorded, as their subjects did not survive, and which are not a story about the Righteous, but about blackmail, denunciation, exploitation, expulsion, persecution, robbery and death. (...) It is still not enough to repeat that [the Righteous - author] DID NOT [emphasis - original] act (...) on behalf of the Polish nation. (...) they acted AGAINST [emphasis - original], and not with the consent of the majority, becoming a minority in their own country, with everything that this entails." (Keff et al., 2014). Dedicating further fragments of the public space to the Righteous may lead to an unjustified, in Jan Grabowski's opinion (2014), conviction that "helping Jews
} 
In striving to identify these tragic points in the historical time-space, it should be of primary importance to make them parts of the collective consciousness. It is, therefore, paramount that the locations of these events become sites of focus for tragic Jewish stories, and assume characteristics that would transform them into carriers of memory of the victims. They should become the attachment points for the local and non-local identities (a source of realisation that it happened in this particular town, or its vicinity, here, no matter how hard it is now to say where exactly). The creation of a new space-time relationship is facilitated by the dynamics of those places which "are" and at the same time, due to various interactions, "become." The willingness to experience empathy ${ }^{76}$, resulting, among other things, from an awareness of participating in the common cultural heritage of the area, can be a significant incentive to establish such a place. Even though this will lead to a violation of the cultural order of the perception of a given section of space, which has been established throughout the post-war period.

Now the points marked by the abyss of pain are generally sites of no memory and, therefore, not recognised by the local community. If this amnesia can be overcome, which means that their status is subject to change ("they become"), it is rather from the outside, as a result of discourse outside the local community (e.g. by participants and witnesses of events, researchers, and activists discovering the history of small homelands) and on the basis of criteria determined without its influence.

The sites of mass murder of Jews are also places that do not serve the local population to root their memory because they were "abandoned" and unmarked. Unlike the sites of non-memory, they are present in the life of local communities, but according to R. Sendyka (2013, pp. 280-281, 283), omitted and unnamed, as sites of taboo. "The memory of them is not revealed in the order of material culture (no plaques are placed on them)." (Sendyka, 2013, p. 280). According to the researcher, “(...) the community topographically assigned to a location has no need or even willingness to locate" their memory in these places, it wants to forget about them, it prefers not to remember them (Sendyka, 2013, p. 281). R. Sendyka also noted that " $(. .$.$) the quality that characterises (...) is their invisibility, transpar-$ ency (...)" (Sendyka, 2013, p. 283). They are so inconvenient for the community around them that it treats their commemoration as a greater threat to collective identity than their abandonment (Sendyka, 2013, p. 281). Thus, they are, to use a term by C. Lanzmann, the director of the film Shoah (in: Sendyka, 2013, p. 279), "non-sites of memory 77 ."

\footnotetext{
was natural and that most of their 'Aryan' fellow citizens at least looked at the dying Jews with sympathy. Nothing could be more wrong."

${ }^{76}$ A. Łebkowska (2018, p. 18) used the phrase "a desire to experience empathy" in her book.

${ }^{77}$ Shoah, directed by Claude Lanzmann, year of production: 1985.
} 


\section{CONCLUSION}

By submitting to the hermeneutics of (non-)sites of (non-)memory, one can come to the conclusion that text remains one such site of recovering memory. It makes the past the present by passing on fractions of someone's memory (often mutilated), accounts of survivors and witnesses or discovering the content of archival sources devoted to dramatic situations. It gives an opportunity to "saturate" these (non-)sites with the reader's reflection and imagination, by dint of which it is possible to identify, not only topographically, traces of traumatic events obscured by layers of ignorance, forgetting, indifference, ignorance or silence ${ }^{78}$. In these loci, partially hollow ${ }^{79}$ and devoid of content, with a more or less identifiable scope, let us restore the memory of the lives of the Holocaust survivors, cut short in them.

\section{REFERENCES}

ADELSON, J. (1993), 'W Polsce zwanej Ludową', [in:] TOMASZEWSKI, J. (ed.), Najnowsze dzieje Żydów w Polsce. W zarysie (do 1950) roku, Warsaw, pp. 387-477.

BAŃKOWSKA, A., JARZĘBOWSKA, A. and SIEK, M. (2009), 'Morderstwa Żydów w latach 1944-1946 na terenie Polski na podstawie kwerendy w zbiorze 301 (Relacje z Zagłady) w Archiwum Żydowskiego Instytutu Historycznego', Kwartalnik Historii Żydów, 3 (231).

BIKONT, A. (2004), My z Jedwabnego, Warsaw.

BLUS-WĘGROWSKA, D. (1996), 'Atmosfera pogromowa', Karta, 18, pp. 87-106.

CAŁA, A. (2000), 'Kształtowanie się polskiej i żydowskiej wizji martyrologicznej po II wojnie światowej', Przeglad Socjologiczny, 2, pp. 167-180.

CAŁA, A. (2014), Ochrona bezpieczeństwa fizycznego Żydów w Polsce powojennej. Komisje Specjalne przy Centralnym Komitecie Żydów w Polsce, Warsaw.

CAŁA, A. and DATNER-ŚPIEWAK, H. (1997), Dzieje Żydów w Polsce 1944-1968. Teksty źródtowe, Warsaw.

CHOŁODOWSKI, M. (2017), Żydówki umarly trzy razy. Trudna pamięć, http://bialystok.wyborcza. $\mathrm{pl} /$ bialystok/7,35241,22092140,zydowki-umarly-trzy-razy.html?fbclid=IwAR1D08NL_KMV43DicX-1zEkzn9PJPyBH_13FYqh_NO1MilwCztdaW60zgSk\&disableRedirects=true\#BoxLokBialLink [accessed on: 14.07.2019].

CZUBRYT-BORKOWSKI, Cz. (ed.) (1988), Przewodnik po upamiętnionych miejscach walk i męczeństwa; lata wojny 1939-1945, Warsaw.

DATNER, S. (1966), 'Eksterminacja ludności żydowskiej w Okręgu Białostockim’, Biuletyn Żydowskiego Instytutu Historycznego, 60, pp. 3-50.

\footnotetext{
${ }^{78}$ It is almost an encroachment on the area of post-memory, which, in the context of the interpretation of sites of memory, is seen as an affirmation created by the power of empathy able to saturate hollow spaces with the viewer's imagination (Delaperriére, 2013).

${ }^{79}$ The term was taken from the work of J. Leociak (2007, p. 494), who used it to refer to the area of the former Warsaw Ghetto: "The place has survived, but it's been hollowed out, devoid of 'content', 'interior'. The ghetto, which was here, was exterminated, but this 'here' remained, only covered with another presence. All that is left is a frame with a different reality, a topographical point, a cartographic abstraction."
} 
DATNER, H. and MELCHIOR, M. (1997), ‘Żydzi we współczesnej Polsce - nieobecność i powroty', [in:] KURCZ, Z. (ed.), Mniejszości narodowe w Polsce, Wrocław, pp. 63-81.

DELAPERRIÉRE, M. (2013), 'Miejsca pamięci czy pamięć miejsc? Kilka refleksji na temat uobecniania przeszłości w literaturze współczesnej’, Ruch literacki, LIV, 1 (316), pp. 49-61. https:// doi.org/10.2478/v10273-012-0054-7

DMITRÓW, E. (2002), 'Oddziały operacyjne niemieckiej Policji Bezpieczeństwa i Służby Bezpieczeństwa a początek zagłady Żydów w Łomżyńskiem i na Białostocczyźnie latem 1941 roku', [in:] MACHCEWICZ, P. and PERSAK, K. (eds.), Wokół Jedwabnego, 1, Studia, Warsaw, pp. 273-352.

DOMANOWSKA, A. (2012), Zbrodnia sprzed lat. Bili kosami i motykami. Żydówki się nie bronity, https://bialystok.wyborcza.pl/bialystok/1,35241,11937426,Zbrodnia_sprzed_lat_Bili_kosami_i_motykami_Zydowki.html [accessed on: 14.07.2019].

ENGEL, D. (1998), 'Patterns of Anti-Jewish Violence in Poland 1944-1946', Yad Vashem Studies, 26, pp. 43-85.

ENGELKING, B. (2011), Jest taki piękny słoneczny dzień. Losy Żydów szukajacych ratunku na wsi polskiej 1942-1945, Warsaw.

ENGELKING, B. and GRABOWSKI, J. (eds.) (2011), Zarys krajobrazu. Wieś polska wobec zagłady Żydów 1942-1945, Warsaw.

ENGELKING, B. and GRABOWSKI, J. (eds.) (2018), Dalej jest noc. Losy Żydów w wybranych powiatach okupowanej Polski, I i II, Warsaw.

GRABOWSKI, J. (2008), 'Ratowanie Żydów za pieniądze: przemysł pomocy', Zagłada Żydów. Studia i Materiaty, 4, pp. 81-109. https://doi.org/10.32927/ZZSiM.268

GRABOWSKI, J. (2011), Judenjagd. Polowanie na Żydów 1942-1945. Studium dziejów pewnego powiatu, Warsaw.

GRABOWSKI, J. (2014), Upamiętnianie Polaków niosacych pomoc, https://krytykapolityczna.pl/ kraj/grabowski-upamietnianie-polakow-niosacych-pomoc/2014/ [accessed on: 14.05.2019].

GRABSKI, A. (2002), Żydowski ruch kombatancki w Polsce 1944-1949, Warsaw.

GRABSKI, A. (2004), Działalność komunistyczna wśród Żydów w Polsce (1944-1949), Warsaw.

GRABSKI, A (ed.) (2007), Żydzi a lewica. Zbiór studiów historycznych, Warsaw.

GRABSKI, A. and RYKAŁA, A. (2010), 'Żydzi w Polsce 1944-2010', [in:] SIENKIEWICZ, W. (ed.), Atlas historii Żydów polskich, Warsaw.

GROSS, J. T. (2000), Sasiedzi. Historia zagłady żydowskiego miasteczka, Sejny.

GROSS, J. T. (2002), ‘Antoniemu Sułkowi w odpowiedzi’, Więź, 4, pp. 82-89. https://doi.org/10.1007/ 978-3-663-10626-5_5

GROSS, J. T. (2003), Wokót „Sąsiadów”: polemiki i wyjaśnienia, Sejny.

GROSS, J. T. (2008), Strach. Antysemityzm w Polsce tuż po wojnie. Historia moralnej zapaści, Krakow.

GRYNBERG, M. (1986), Żydowska spółdzielczość pracy w Polsce w latach 1945-1949, Warsaw. https://sztetl.org.pl [accessed on: 18.05.2018].

HURWIC-NOWAKOWSKA, I. (1996), Żydzi polscy (1947-1950). Analiza więzi społecznej ludności żydowskiej, Warsaw.

IPN wyrzuca naukowców. Polaków można przedstawiać tylko $w$ dobrym świetle, interview by Alina Pospischil with Adam Puławski, 2018, Duży Format suplement to Gazeta Wyborcza, 8 X, pp. 21-23.

JABŁONSSKI, Z. (1998), 'Ochrona dziedzictwa historycznego w krajobrazie a działalność samorządów terytorialnych’, [in:] JABŁOŃSKI, Z., TOMASZEWSKI, W. (eds.), Ochrona wartości przyrodniczych i kulturowych - metodyka opracowań studialnych, series: Przeglad Regionalny, 3, 1, Toruń, pp. 33-42.

JANICKA, E., KEFF, B. and DATNER, E. (2014), 'Polska panika moralna. Czy upamiętnić Sprawiedliwych koło Muzeum Historii Żydów Polskich’, Gazeta Wyborcza, 31 V-1 VI, p. 39. 
KACZYŃSKI, A. (2000a), 'Całopalenie. W Jedwabnem zagłady Żydów Niemcy dokonali polskimi rękami’, Rzeczpospolita, $5 \mathrm{~V}$, pp. 1-3.

KACZYŃSKI, A. (2000b), 'Oczyszczenie pamięci', Rzeczpospolita, 19 V, p. 6.

KAINER, A. (1983), ‘Żydzi a komunizm', Krytyka. Kwartalnik polityczny, 15, pp. 214-247.

KALETA, E. (2018), 'Mój rodzinny żydowski dom', Duży Format suplement to Gazeta Wyborcza, 19 XI, pp. 18-19.

KĄCKI, M. (2016), Znalazłem je. Historia mordu na Żydówkach ze Szczuczyna, https://wyborcza. pl/duzyformat/1,127290,20623463,znalazlem-je-historia-mordu-zydowek-ze-szczuczyna.html [accessed on: 14.07.2019].

KEFF, B., DATNER, H. and JANICKA, E. (2014), 'Nie budujmy pomnika Sprawiedliwych obok Muzeum Historii Żydów Polskich', Krytyka Polityczna, 29 IV. https://krytykapolityczna.pl/kraj/ nie-budujmy-pomnika-sprawiedliwych-obok-muzeum-historii-Zydow-polskich/ [accessed on: 15.12.2018].

KENDZIOREK, P. (2016), Program i praktyka produktywizacji Żydów polskich $w$ działalności CKŻP, Warsaw.

KERSTEN, K. (1992), Polacy - Żydzi-komunizm. Anatomia pótprawd 1929-1968, Warsaw.

KERSTEN, K. (1993), Między wyzwoleniem a zniewoleniem. Polska 1944-1956, London.

KOPCIOWSKI, A. (2007), 'Zajścia antyżydowskie na Lubelszczyźnie w pierwszych latach po drugiej wojnie światowej’, Zagłada Żydów. Studia i Materiały, 3, pp. 178-207. https://doi. org/10.32927/ZZSiM.228

KURAŚ, B. (2016), 'Zbrodnia na Żydach w Krościenku. «Mały jęczy, trzeba poprawić»', Gazeta Wyborcza, 28-29 V, pp. 32-33.

KWIEK, J. (2013), 'Zabójstwa ludności żydowskiej w Krakowskiem w latach 1945-1947. Fakty i mity’, Kwartalnik Historii Żydów, 4.

LEOCIAK, J. (2007), 'Warszawa: „Miejsce-po-getcie” jako palimpsest', [in:] MADUROWICZ, M. (ed.), Percepcja wspótczesnej przestrzeni miejskiej. Praca zbiorowa, Warsaw, pp. 493-495.

LIBIONKA, D. (2006), 'Losy Chaima Hirszmana jako przyczynek do refleksji nad pamięcią o Zagładzie i powojennymi stosunkami polsko-żydowskimi', [in:] EISLER, J., SZAROTA, T. (eds.), Polska 1944/45-1989. Studia i materiały, 7, pp. 5-23, Warsaw.

ŁEBKOWSKA, A. (2008), Empatia. O literackich narracjach przełomu XX i XXI wieku, Krakow.

MACHCEWICZ, P. and PERSAK, K. (eds.) (2002), Wokót Jedwabnego, 1: Studia, 2: Dokumenty, Warsaw.

MAJEWSKI, T. (2011), 'Ulice bez pamięci', [in:] MAJEWSKI, T., ZEIDLER-JANISZEWSKA, A. (eds.), Pamięć Shoah. Kulturowe reprezentacje i praktyki upamiętniania, Łódź, pp. 209-211.

MILEWSKI, J. J. (2002), 'Zagłada Żydów w Wąsoszu w świetle akt sprawy karnej Mariana Rydzewskiego’, Biuletyn Historii Pogranicza, 3, pp. 87-112.

MONKIEWICZ, W. (1989), 'Zagłada skupisk żydowskich w regionie białostockim w latach 1939, 1941-1944', Studia Podlaskie, 2, pp. 336-354.

MOROZ, A. (2016), 'Konflikt pamięci na pograniczu polsko-białoruskim na przykładzie działalności Romualda Rajsa ps. «Bury»', Studia z Geografii Politycznej i Historycznej, 5, pp. 61-91. https://doi.org/10.18778/2300-0562.05.04

MYGA-PIĄTEK, U. (2012), Krajobrazy kulturowe. Aspekty ewolucyjne i typologiczne, Katowice.

'Nad mogiłą Męczenników. Kazanie, wygłoszone w Kielcach dn. 7 VII 1946 r. nad otwartym grobem 40 ofiar pogromu kieleckiego', Opinia, 2, 25 July 1946 r., 7.

NALEWAJKO-KULIKOV, J. (2009), Obywatel Jidyszlandu. Rzecz o żydowskich komunistach $w$ Polsce, Warsaw.

NORA, P. (1984), Les Lieux de mémorie, sous la direction de Pierre Nora, 1, Paris.

ORŁOWSKA, E. (2005), 'Kulturowy aspekt badań geograficznych', [in:] MYGA-PIĄTEK, U. (ed.), Krajobraz kulturowy. Aspekty teoretyczne i metodologiczne, series: Prace Komisji Krajobrazu Kulturowego PTG, 4, pp. 55-64. 
PACZKOWSKI, A. (2001), 'Żydzi w UB: próba weryfikacji stereotypu’, [in:] SZAROTA, T. (ed.), Komunizm: ideologia - system - ludzie, Warsaw.

PINCHUK, B. C. (1991), Shtetl Jews under the Soviet Rule. Eastern Poland on the Eve of the Holocaust, Cambridge MA.

PISARSKI, M. (1997), 'Emigracja Żydów z Polski w latach 1945-1951', [in:] GRABSKI, A., PISARSKI, M. and STANKOWSKI, A. (eds.), Studia z dziejów i kultury Żydów w Polsce po $1945 r$., Warsaw, pp. 13-81.

PLIT, J. (2016), Krajobrazy kulturowe Polski i ich przemiany, series: Prace Geograficzne, 253, Warsaw.

Pomnikowi Sprawiedliwych przy muzeum Polin? Bojownicy z getta sa przeciw: http://warszawa. wyborcza.pl/warszawa/1,34862,17288913,Pomnikowi_Sprawiedliwych_przy_muzeum_Polin_Bojownicy.html [accessed on: 15.12.2018].

RESZKA, P. P. (2019), Płuczki. Poszukiwacze żydowskiego złota, Warsaw.

ROSNER, A. M. (2018), Obraz społeczności ocalałych w Centralnej Kartotece Wydziału Ewidencji i Statystyki CKŻP, Warsaw.

ROTEM, S. (2018) 'List powstańca z warszawskiego getta do Andrzeja Dudy', Gazeta Wyborcza, 28-29 April 2018.

RYKAŁA, A. (2007), Przemiany sytuacji społeczno-politycznej mniejszości żydowskiej w Polsce po drugiej wojnie światowej, Łódź: Wydawnictwo Uniwersytetu Łódzkiego.

RYKAŁA, A. (2018), “O „topografii pustki” w krajobrazie kulturowym. Miejsca niepamięci, nie-miejsca pamięci w kontekście mordów dokonanych na Żydach w Polsce w pierwszych miesiącach po drugiej wojnie światowej’, Studia z Geografii Politycznej i Historycznej, 7, [in:] FIGLUS, T. (ed.), Wspótczesne badania geograficzno-historyczne krajobrazu kulturowego. https://doi.org/10.18778/2300-0562.07.04

RYKAŁA, A. (2019), 'Pogrom w Kielcach w 1946 r. a odbudowa skupisk żydowskich - ujęcie geograficzne', [in:] GRABSKI, A. (ed.), Pogromy Żydów na ziemiach polskich w XIX i XX wieku, t. 4: Holokaust i powojnie (1939-1946), Warsaw.

RYKAŁA, A. (2020), W reakcji na powojenna przemoc antysemicka. Samoobrona Żydów w Łodzi - uwarunkowania społeczno-polityczne i przestrzenne, Łódź.

RYKAŁA, A. and WOSIAK, A. (2019), 'Geograficzno-historyczne (polityczne) uwarunkowania genezy i przebiegu wybranych pogromów Żydów na ziemiach polskich od XIX w. do 1946 r.', [in:] GRABSKI, A. (ed.), Pogromy Żydów na ziemiach polskich w XIX $i$ XX wieku, t. 4: Holokaust i powojnie (1939-1946), Warsaw.

SCHAMA, S. (1996), Landscape and Memory, New York.

SENDYKA, R. (2013), 'Pryzma - zrozumieć nie-miejsce pamięci', [in:] CZAJA, D. (ed.), Inne przestrzenie, inne miejsca. Mapy i terytoria, Wołowiec, pp. 278-299.

SKIBIŃSKA, A. (2007), 'Powroty ocalałych', [in:] ENGELKING, B., LEOCIAK, J. and LIBIONKA, D. (eds.), Prowincja noc. Życie i zagłada Żydów w dystrykcie warszawskim, Warsaw.

SKIBIŃSKA, A. (2011), 'Powroty ocalałych i stosunek do nich społeczeństwa polskiego', [in:] TYCH, F. and ADAMCZYK-GARBOWSKA, M. (eds.), Nastęstwa zagłady Żydów. Polska 1944-2010. Praca zbiorowa, Lublin.

STRZEMBOSZ, T. (2001), 'Przemilczana kolaboracja', Rzeczpospolita, 27 I, pp. 6-7.

SUŁEK, A. (2001), 'Sąsiedzi - zwykła recenzja', Więź, 12, pp. 72-99.

SZAYNOK, B. (2006), 'Polacy i Żydzi. Lipiec 1944-lipiec 1946', [in:] KAMIŃSKI, Ł. and ŻARYN, J. (eds.), Wokót pogromu kieleckiego, Warsaw, pp. 9-24.

ŚMIETANKA-KRUSZELNICKI, R. (2006), 'Pogrom w Kielcach - podziemie w roli oskarżonego', [in:] KAMIŃSKI, Ł. and ŻARYN, J. (eds.), Wokót pogromu kieleckiego, Warsaw, pp. $25-74$.

ŚPIEWAK, P. (2012), Żydokomuna. Interpretacje historyczne, Warsaw.

TOKARSKA-BAKIR, J. (2012), Okrzyki pogromowe. Szkice z antropologii historycznej Polski lat 1939-1946, Wołowiec. 
TOKARSKA-BAKIR, J. (2018a), Pod klątwa. Spoleczny portret pogromu kieleckiego, 1, 2: Dokumenty, Warsaw.

TOKARSKA-BAKIR, J. (2018b), ‘Tryby maszyny pogromu', Ale Historia, 19 II, pp. 4-7.

TRYCZYK, M. (2015), '1941: Pogrom Żydów w Radziłowie. Zasypali ją w płytkim rowie’, Duży Format suplement to Gazeta Wyborcza, 13 January 2020.

TRYCZYK, M. (2015), Miasta śmierci. Sąsiedzkie pogromy Żydów, Warsaw.

TUWIM, J. (1993), My, Żydzi polscy..., Warsaw.

URYNOWICZ, M. (2002), 'Ludność żydowska w Jedwabnem. Zmiany demograficzne od końca XIX wieku do 1941 roku na tle regionu łomżyńskiego', [in:] MACHCEWICZ, P. and PERSAK, K. (eds.), Wokót Jedwabnego, 1: Studia, Warsaw, pp. 83-104.

WÓJCIK, J. (2016). Oddziat. Między AK i UB - historia żolnierzy Lazika, Warsaw.

WRONISZEWSKA, D. and WRONISZEWSKI, A. (1988), '...aby żyć', Kontakty, 10 VII, 1, pp. 8-9.

WYKA, K. (1945), Odrodzenie, 9 September 1945, p. 41. (second quotation).

WYKA, K. (1945), 'Potęga ciemnoty potwierdzona', Odrodzenie, 23 September 1945, 32.

ZAREMBA, M. (2012), Wielka trwoga. Polska 1944-1947. Ludowa reakcja na kryzys, Kraków.

Zarys działalności Centralnego Komitetu Żydów w Polsce za okres od 1 stycznia do 30 czerwca 1946 roku, (1947), Warsaw.

ZGLICZYŃSKI, S. (2013), Jak Polacy Niemcom Żydów mordować pomagali, Warsaw.

ŻBIKOWSKI, A. (1992), 'Lokalne pogromy Żydów w czerwcu i lipcu 1941 roku na wschodnich rubieżach II Rzeczypospolitej’, Biuletyn Żydowskiego Instytutu Historycznego, 2/3, pp. 3-18.

ŻBIKOWSKI, A. (2002), 'Pogromy i mordy ludności żydowskiej w Łomżyńskiem i na Białostocczyźnie latem 1941 roku w świetle relacji ocalałych Żydów i dokumentów sądowych', [in:] MACHCEWICZ, P. and PERSAK, K. (eds.), Wokót Jedwabnego, 1: Studia, Warsaw, pp. 159271.

ŻBIKOWSKI, A. (2006), U genezy Jedwabnego. Żydzi na Kresach Pótnocno-Wschodnich II Rzeczypospolitej, wrzesień 1939-lipiec 1941, Warsaw.

ŻBIKOWSKI, A. (2011), 'Morderstwa popełniane na Żydach w pierwszych latach po wojnie', [in:] TYCH, F. and ADAMCZYK-GARBOWSKA, M. (eds.), Następstwa zagłady Żydów. Polska 1944-2010. Praca zbiorowa, Lublin, pp. 71-93.

ŻBIKOWSKI, A. (2018), 70 lat badań nad dziejami polskich Żydów. Pisane z perspektywy historyka Zagłady, Żydowski Instytut Historyczny, Warsaw. 